\title{
Multiple Actions of 1S,3R-ACPD in Modulating Endogenous Synaptic Transmission to Spinal Respiratory Motoneurons
}

\author{
Xiao-Wei Dong, ${ }^{1}$ Didier Morin, ${ }^{1}$ and Jack L. Feldman ${ }^{1,2}$ \\ Systems Neurobiology Laboratory, Departments of ${ }^{1}$ Physiological Science and ${ }^{2}$ Neurobiology, University of California at \\ Los Angeles, Los Angeles, California 90095-1527
}

\begin{abstract}
To determine physiological roles of metabotropic glutamate receptors (mGluRs) affecting breathing, we examined the effects of (1S,3R)-1-aminocyclopentane-1,3-dicarboxylic acid (1S,3R-ACPD) on synaptic transmission and excitability of phrenic motoneurons (PMNs) in an in vitro neonatal rat brainstem/spinal cord preparation. The effects of 1S,3R-ACPD were multiple, including reduction of inspiratory-modulated synaptic currents and increase of neuronal excitability via an inward current $\left(I_{\text {acpd }}\right)$ associated with a decrease of membrane conductance. The mechanism underlying synaptic depression was examined. We found that 1S,3R-ACPD reduced the frequency but not the amplitude of miniature excitatory postsynaptic currents. The current induced by exogenous AMPA was not significantly affected by 1 S,3R-ACPD. These results suggest that 1S,3R-ACPD-induced reduction of inspiratory synaptic currents is mediated by presynaptic mGluRs. We also examined the ionic basis for $I_{\text {acpd }}$. We found that $I_{\text {acpd }}$ had a reversal
\end{abstract}

Glutamate, acting via ionotropic receptors, is the principal fast excitatory neurotransmitter in the mammalian CNS. Glutamate also modulates neuronal excitability by activation of metabotropic glutamate receptors (mGluRs), which couple through GTPbinding proteins to intracellular second messenger cascades (Sladeczek et al., 1985; Sugiyama et al., 1987; Cartmell et al., 1992; Schoepp et al., 1992; Winder and Conn, 1992). There are at least eight subtypes of mGluR with distinct pharmacological profiles and second messenger activities (Houamed et al., 1991; Masu et al., 1991; Abe et al., 1992; Tanabe et al., 1992, 1993; Nakajima et al., 1993; Okamoto et al., 1994). mGluRs therefore may play a complex role in regulation of synaptic transmission in the CNS. This is apparent in examining the effects of a broad spectrum agonist, trans-( \pm )-1-aminocyclopentane-1,3-dicarboxylic acid (trans-ACPD), on neuronal function. In hippocampal neurons, trans-ACPD increases neuronal excitability (Charpak et al., 1990; Desai and Conn, 1991) by inhibiting several $\mathrm{K}^{+}$conductances, including a voltage-gated, a $\mathrm{Ca}^{2+}$-activated, and a $\mathrm{Ba}^{2+}$-sensitive tonically activated $\mathrm{K}^{+}$conductance (Charpak et al., 1990; Guerineau et al., 1994). Activation of mGluRs can also attenuate

\footnotetext{
Received Feb. 20, 1996; revised May 22, 1996; accepted May 28, 1996.

This work was supported by National Institutes of Health Grant NS24742 and the Conseil Régional Provence-Alpes-Cotes d'Azur.

Correspondence should be addressed to Xiao-Wei Dong, Department of Physiological Science, University of California at Los Angeles, P.O. Box 951527, Los Angeles, CA 90095-1527.

Dr. Morin's present address: Laboratoire des Neurosciences de la Motricité, Université Bordeaux I, Centre National de la Recherche Scientifique, Unité de Recherche Associée 339, Avenue des Facultés, 33405 Talence, France.

Copyright (C) 1996 Society for Neuroscience $0270-6474 / 96 / 164971-12 \$ 05.00 / 0$
}

potential of approximately $-100 \mathrm{mV}$, close to the estimated $E_{\mathrm{K}^{+}}$ $(-95 \mathrm{mV})$. Elevating extracellular $\left[\mathrm{K}^{+}\right]$to $9 \mathrm{~mm}$ reduced the $I_{\text {acpd }}$ reversal potential to $-75 \mathrm{mV}$. The $\mathrm{K}^{+}$channel blocker $\mathrm{Ba}^{2+}$ induced an inward current with a reversal potential at $-93 \mathrm{mV}$ associated with a decrease of membrane conductance, closely resembling the effect of 1S,3R-ACPD. Moreover, $\mathrm{Ba}^{2+}$ occluded 1S,3R-ACPD effects. In the presence of $\mathrm{Ba}^{2+}, I_{\text {acpd }}$ and the 1S,3R-ACPD-induced decrease of membrane conductance were diminished. Our data indicate that the dominant component of $I_{\text {acpd }}$ results from the blockade of a $\mathrm{Ba}^{2+}$-sensitive resting $\mathrm{K}^{+}$conductance. We conclude that the activation of mGluRs affects the inspiratory-modulated activity of PMNs via distinct mechanisms at pre- and postsynaptic sites.

Key words: 1S,3R-ACPD; metabotropic glutamate receptors; synaptic transmission; presynaptic; excitability; potassium channels; brainstem; spinal cord; phrenic motoneurons; respiration synaptic transmission in, for example, hippocampus (Koerner and Cotman, 1981; Yamamoto et al., 1983; Forsythe and Clements, 1990; Baskys and Malenka, 1991; Gereau and Conn, 1995), nucleus of the tractus solitarius (Glaum et al., 1992), cerebellum (Llano and Marty, 1995), and striatum (Lovinger and McCool, 1995); the responsible mGluRs may be located presynaptically.

The diversity of mGluR actions may provide a wide dynamic range for modulation of neuronal excitability. Although information is accumulating from studies that examine actions of mGluRs in slice preparations (Glaum et al., 1992; McBain et al., 1994), the functional and physiological roles of mGluR action in identified neurons with measurable behaviors warrants investigation. We therefore examined the effects of mGluR activation on phrenic motoneurons (PMNs), which innervate the diaphragm and retain spontaneous endogenous inspiratory-modulated synaptic inputs in an in vitro brainstem/spinal cord preparation (Smith and Feldman, 1987). The transmission of inspiratory drive to PMNs is mediated by an excitatory amino acid (EAA), presumably glutamate (McCrimmon et al., 1989; Liu et al., 1990) acting primarily at non-NMDA receptors (Liu et al., 1990; Feldman and Smith, 1994), allowing us to study mGluR actions at an identified, endogenously driven glutamatergic synapse onto a functionally identified neuron. We determined actions of mGluRs on PMN excitability by examining the effects of an mGluR agonist on endogenous inspiratory-modulated synaptic currents and postsynaptic membrane properties. To investigate possible mechanisms underlying mGluR actions on synaptic transmission, we analyzed the frequency and amplitude of miniature excitatory postsynaptic currents (mEPSCs). We also examined ionic currents underlying 
mGluR actions on membrane properties by using channel blockers and ion manipulation. We then investigated the functional consequence of mGluR activation by examining the effects on neuronal firing behavior.

Preliminary reports of this work have been published previously in abstract form (Dong et al., 1994; Morin et al., 1994).

\section{MATERIALS AND METHODS}

En bloc preparation. Experiments were performed on in vitro preparations of brainstem and spinal cord from 0 - to 4 -d-old neonatal rats. Results reported were obtained from 65 preparations (11, day $0 ; 21$, day $1 ; 19$, day $2 ; 10$, day 3; and 4, day 4). Details of the preparation have been described (Smith and Feldman, 1987; Liu et al., 1990; Dong and Feldman, 1995). In brief, the brainstem and cervical spinal cord were isolated from 0 - to 4-d-old ether-anesthetized Sprague-Dawley rats. The en bloc neuraxis was pinned down with ventral surface upward on Sylgard resin in a recording chamber and superfused continuously with normal artificial cerebrospinal fluid (aCSF) containing (in $\mathrm{mM}$ ): $128 \mathrm{NaCl}, 3 \mathrm{KCl}, 1.5$ $\mathrm{CaCl}_{2}, 1.0 \mathrm{MgSO}_{4}, 21 \mathrm{NaHCO}_{3}, 0.5 \mathrm{NaH}_{2} \mathrm{PO}_{4}$, and 30 D-glucose, equilibrated with $95 \% \mathrm{O}_{2} / 5 \% \mathrm{CO}_{2}$. The bath temperature was gradually raised from $18-20^{\circ} \mathrm{C}$ (for isolation) to $25-26^{\circ} \mathrm{C}$ before recording.

Electrophysiology. Respiratory activity was recorded with suction electrodes from the $\mathrm{C}_{4}$ ventral root, which contains PMN axons, and sometimes simultaneously from cranial nerves (X, XII). Signals were amplified (Grass P511K; Grass Instrument, Quincy, MA), rectified, and low-pass filtered (Paynter filter; $\tau=15 \mathrm{msec}$ ).

Electrodes for whole-cell patch-clamp recordings were pulled from aluminosilicate glass (A-M Systems, Everett, WA) with tip size $\sim 2 \mu \mathrm{m}$ and resistance 3.5-5.0 $\mathrm{M} \Omega$ when filled with solution containing (in $\mathrm{mM}$ ): $120 \mathrm{~K}^{+}$-gluconate, $1 \mathrm{CaCl}_{2}, 5 \mathrm{NaCl}, 10 \mathrm{HEPES}, 2$ ATP (magnesium salt), 10 1,2-bis-(2-aminophenoxy) ethane- $N, N, N^{\prime}, N^{\prime}$-tetra-acetic acid (BAPTA) (tetrapotassium salt), $\mathrm{pH}$ 7.3, adjusted by KOH. Successful whole-cell recording was assured by the initial formation of gigaohm seal $(2-10 \mathrm{G} \Omega)$ and low series resistance $\left(R_{\mathrm{S}} ; 8-15 \mathrm{M} \Omega\right)$. $R_{\mathrm{S}}$ was estimated using $100 \mathrm{~Hz},-10 \mathrm{mV}, 5 \mathrm{msec}$ voltage pulses. When in voltage-clamp mode, a $60-80 \% R_{\mathrm{S}}$ compensation was used. During the experiment, $R_{\mathrm{S}}$ was checked frequently, and data were discarded if large increases occurred during the course of the recording. Cells were voltage-clamped at the end-expiratory potentials of -60 to $-75 \mathrm{mV}$. Data obtained from cells displaying fast $\mathrm{Na}^{+}$currents during inspiration (indicative of poor voltage control over the inspiratory-modulated synaptic current) were not included in the analysis. Signals were amplified with a patch-clamp amplifier (Axopatch 1D/or Axopatch 200, Axon Instruments, Foster, CA) and filtered at $2-5 \mathrm{kHz}$ (Bessel filter).

Current-voltage $(I-V)$ relations were obtained by applying a series of command voltage step pulses (step size, $2-5 \mathrm{mV}$; width, $100-200 \mathrm{msec}$; frequency, $2 \mathrm{~Hz}$ ) controlled by software (Axodata, Axon Instruments). $I-V$ curves were obtained by plotting current change (averaged steadystate current values at $5-10 \mathrm{msec}$ before offset of voltage step) against membrane potential. Because most PMNs did not exhibit slow timedependent membrane properties over the testing voltage range and the membrane current reached steady state at $50 \mathrm{msec}$ after the onset of the voltage pulse (see Fig. $5 C$ ), steady-state current could be obtained using voltage pulses with width $\geq 100 \mathrm{msec}$. Membrane potentials $\left(V_{\mathrm{m}}\right)$ were adjusted for liquid junction potentials $(-10 \mathrm{mV}$ for the solution contained in the recording electrode). Neuron input conductance $\left(G_{\mathrm{N}}\right)$ was calculated at holding potential $(-60$ to $-75 \mathrm{mV})$ from the slope of a least-squares regression line fitted to the data.

Repetitive firing properties were examined using current pulses $(0.4$ $\mathrm{nA} ; 1 \mathrm{sec}$ ) during the expiratory phase. Instantaneous firing frequency was calculated as the reciprocal of the interspike interval.

Neurons subjected to experimental measurements and data analysis satisfied the criteria described previously (Liu et al., 1990; Lindsay and Feldman, 1993). Briefly, these neurons had resting membrane potentials of at least $-60 \mathrm{mV}$ and displayed rhythmic synaptic drive currents in synchrony with the inspiratory burst activity on the $\mathrm{C}_{4}$ ventral root. These neurons were located at intermediate laterality and 130-300 $\mu \mathrm{m}$ below the ventral surface at the $\mathrm{C}_{4}$ segment, consistent with the location of the PMN pool in neonatal rats (Lindsay et al., 1991). Axons of these neurons were contained in $\mathrm{C}_{4}$ ventral root, indicated by antidromic activation by stimulating the $\mathrm{C}_{4}$ nerve through the suction electrode. Moreover, their other intrinsic properties, such as input resistance, were consistent with the measurements made in neurons identified as PMNs (Smith et al., 1988).
Pharmacological substances and application. The drugs used in our experiments included 1S,3R-ACPD (RBI, Natick, MA) $(5-500 \mu \mathrm{M})$; (R,S)- $\alpha$-methyl-4-carboxyphenylglycine (MCPG) (Tocris Cookson, St. Louis, MO) (0.2-5 mM); 6-cyano-7-nitroquinoxaline-2,3-dione (CNQX) (Tocris Cookson) (100 $\mu \mathrm{M})$; (+)-5-methyl-10,11-dihydro-5H-dibenzo $[a, d]$ cyclohepten-5,10-iminemaleate (MK-801) (RBI) $(250 \mu \mathrm{M})$; AMPA (RBI) $(50 \mu \mathrm{M})$, and tetrodotoxin (TTX) (Sigma, St. Louis, MO) $(1 \mu \mathrm{M})$. Experiments were performed while the preparations were perfused with normal aCSF solution, as described above. For blocking chemical synaptic transmission, a Ca ${ }^{2+}$-free $(0 \mathrm{mM})$, high- $\mathrm{Mg}^{2+}(2.5 \mathrm{mM})$ solution was prepared with equimolar substitution of $\mathrm{MgCl}_{2}$ for $\mathrm{CaCl}_{2}$. For experiments using the $\mathrm{K}^{+}$channel blocker $\mathrm{Ba}^{2+}$, a modified aCSF solution was used to avoid precipitation, containing (in $\mathrm{mm}$ ): $139 \mathrm{NaCl}, 3 \mathrm{KCl}, 1.5$ $\mathrm{CaCl}_{2}, 1.0 \mathrm{MgCl}_{2}, 10 \mathrm{Na}$-HEPES, $0.5 \mathrm{NaH}_{2} \mathrm{PO}_{4}$, and 30 D-glucose, $\mathrm{pH}$ 7.3 , adjusted by $\mathrm{HCl}$. $\mathrm{BaCl}_{2}(2 \mathrm{mM})$ was added to the solution after control data were collected. In experiments to manipulate the $\mathrm{K}^{+}$reversal potential, a perfusion solution with elevated $\mathrm{K}^{+}(9 \mathrm{mM})$ was prepared by equimolar substitution of $\mathrm{KCl}$ for $\mathrm{NaCl}$.

Drugs were added to the spinal cord bath and/or applied locally via a glass pipette over the spinal cord region containing the PMN pool. Bath application was used to determine the minimum concentrations required for drug action and to perform dose-response tests. When this drug administration technique was used, the bath chamber was partitioned into two compartments at the level of the spinomedullary junction by a transverse barrier of petroleum jelly (Vaseline) across the neuraxis. This allowed selective drug application to the spinal cord so as to affect synaptic transmission at the spinal level without disturbing processes at the brainstem level, where the descending inspiratory motor drive originated. Drugs were added to the spinal compartment at concentrations starting from the minimum necessary to induce a clear change in $\mathrm{C}_{4}$ root activity, and 6-8 min was allowed for equilibrium.

Vaseline, necessary for partition, often caused difficulty in obtaining good seals for patch recording. Thus, when such recordings were desired, test agents were applied locally in an unpartitioned chamber via pressure ejection from single or multibarrel electrodes positioned close to the ventral surface of the spinal cord over the PMN pool (Liu et al., 1990). Each barrel had an orifice of $8-10 \mu \mathrm{m}$ and was filled with a drug solution or saline (or aCSF). Application of drugs was controlled by brief air pressure pulses to the appropriate drug barrel. Control injections were made by ejecting saline or aCSF.

In experiments examining drug specificity with $\mathrm{C}_{4}$ root recording, bath application of an antagonist was combined with local application of an agonist. After the effect of a locally applied agonist was examined, an antagonist was added to the spinal compartment and then the agonist was tested again. The application of antagonist began at least 2 min before agonist application and continued during the agonist test. The observed change attributable to a test drug acting at a spinal site rather than at a supraspinal site was indicated by unchanged respiratory rate recorded from $\mathrm{C}_{4}$ root and unchanged amplitude recorded from cranial nerves (X, XII).

Data acquisition and analysis. Data were recorded on videotape via pulse code modulation (Vetter model 3000, A.R. Vetter, Rebersburg, PA) (sampled at $10-40 \mathrm{kHz}$ per channel) for off-line analysis. Selected segments of records were digitized at $5-25 \mathrm{kHz}$ using an analog-to-digital converter and stored on a Vaxstation 3200 computer disk (Digital Equipment, Maynard, MA) for subsequent computer-aided analysis.

For analysis of changes of the respiratory drive, the average values of peak amplitude and area under the envelope of inspiratory-modulated synaptic current or integrated $\mathrm{C}_{4}$ ventral root discharges were computed from respiratory cycles before and after drug application. Statistical values are reported as means \pm SEM. Differences between means were assessed by Student's $t$ test, and a value of $p<0.05$ was considered significant.

For analysis of perturbations of frequency and amplitude of mEPSCs, the data were first filtered using a Wiener (optimal) filter (Press et al., 1989; Barkat, 1991), which greatly attenuates background noise without significantly affecting the characteristics of the original signal (Liu and Feldman, 1992). Events were detected using a threshold detector. Then, under visual inspection, events above noise level were collected for data analysis. The reliability of detection of unitary events was assured by a high signal-to-noise ratio (>2.2) (Liu and Feldman, 1992); the amplitudes of mEPSCs were well above noise level in each cell tested. We did not observe any presumptive mEPSCs of size below 2.2 times the mean noise level. We therefore assume that we detected any spontaneous EPSCs. To ensure identical voltage control before and after drug treatment so that the error in amplitude measurement attributable to inadequate space 


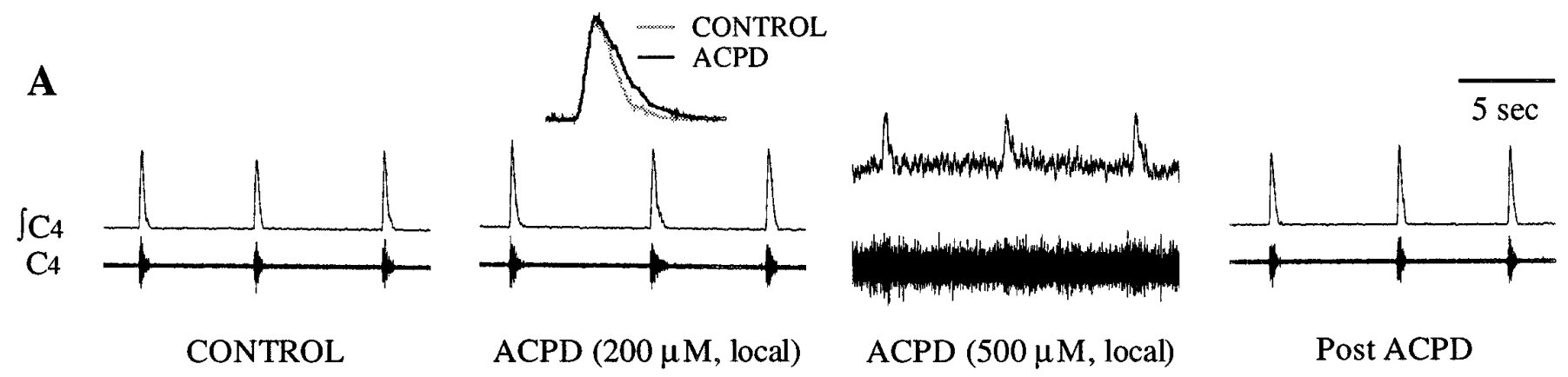

B

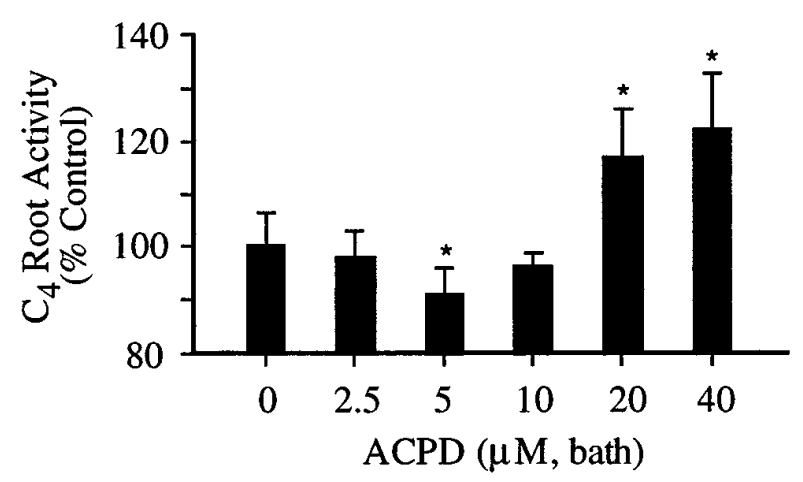

C

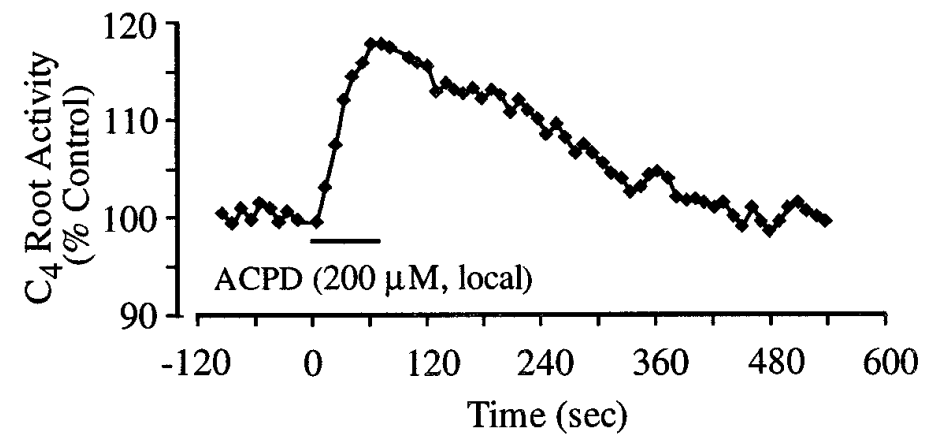

Figure 1. Differential effects of $1 \mathrm{~S}, 3 \mathrm{R}-\mathrm{ACPD}$ on $\mathrm{C}_{4}$ ventral root activity. $A$, After local application of $1 \mathrm{~S}, 3 \mathrm{R}-\mathrm{ACPD}(\geq 200 \mu \mathrm{M})$, inspiratory discharges in $\mathrm{C}_{4}$ root were increased. Tonic activity was induced at $500 \mu \mathrm{M}$. The inset shows the averages of six consecutive inspiratory discharges (integrated) before and after drug application. Traces in 1S,3R-ACPD conditions were obtained from the recordings at 1 min after drug application. The Post ACPD trace was obtained at $10 \mathrm{~min}$ after washout. $C_{4}$, Raw traces of $\mathrm{C}_{4}$ activity; $\int C_{4}$, integrated $\mathrm{C}_{4}$ activity. $B$, Dose-response relationship for $1 \mathrm{~S}, 3 \mathrm{R}$-ACPD effects on $\mathrm{C}_{4}$ inspiratory discharges. Averages of 10 successive integrated inspiratory discharges at each concentration were pooled from seven preparations. Vertical bars, SEM; asterisk, significant difference ( $p<0.05 ; t$ test) from control values. $C$, Time course of the change of inspiratory discharge in response to local application of 1S,3R-ACPD $(200 \mu \mathrm{M})$. Integrated inspiratory discharge expressed as percentage of control value.

clamp would be similar under these two conditions, the series resistance was monitored, and data were discarded if significant increases occurred during the course of the recording. All collected EPSCs were then subject to analysis. For each condition, cumulative probability distribution histograms for interval and amplitude were constructed. Statistical significance for the difference between distributions was assessed by the KolmogorovSmirnov test (Van der Kloot, 1991), and a value of $p<0.05$ was considered significant.

\section{RESULTS}

\section{S,3R-ACPD-induced bimodal changes in respiratory motor output}

In the brainstem/spinal cord preparation, $\mathrm{C}_{4}$ ventral roots (which contain PMN axons) display spontaneous periodic bursts of discharges representing PMN population activity during the inspiratory phase of the respiratory cycle (Fig. 1A). To determine the effects of the mGluR agonist 1S,3R-ACPD on the activity of PMNs, 1S,3R-ACPD was applied to the PMN pool by spinal bath $(5-50 \mu \mathrm{M})$ or local $(50-500 \mu \mathrm{M})$ application (see Materials and Methods). At low concentrations (5-10 $\mu \mathrm{M}$, bath; 50-100 $\mu \mathrm{M}$, local), 1S,3R-ACPD slightly but consistently reduced inspiratory bursts in $\mathrm{C}_{4}$ ventral roots $(n=7)$ (Fig. $\left.1 B\right)$. The maximum reduction $(9 \pm 5 \%)$ was achieved at $5 \mu \mathrm{M}$ 1S,3R-ACPD (bath). The reduction then declined with increasing concentration. Further elevation of 1S,3R-ACPD concentration ( $>10 \mu \mathrm{M}$, bath; $>100 \mu \mathrm{M}$, local) produced dose-dependent increases in the $\mathrm{C}_{4}$ inspiratory discharge $(n=16)$ (Fig. $1 A, B)$. The integrated $\mathrm{C}_{4}$ root discharge was significantly increased to $117 \pm 9 \%$ of control $(n=$ 7) at $20 \mu \mathrm{M}$ 1S,3R-ACPD (bath). At concentrations $\geq 50 \mu \mathrm{M}$ (bath) or $\geq 500 \mu \mathrm{M}$ (local), 1S,3R-ACPD induced tonic activity in the $\mathrm{C}_{4}$ ventral roots, obscuring the rhythmic inspiratory activity (Fig. 1A); quantifying changes in inspiratory discharges became difficult at higher concentrations, and no further analysis was performed. Responses to $1 \mathrm{~S}, 3 \mathrm{R}-\mathrm{ACPD}$ began with one respiratory cycle $(<10 \mathrm{sec})$ after pressure ejection and took $\sim 1 \mathrm{~min}$ to peak (Fig. 1C). With washout, $\mathrm{C}_{4}$ root activity returned to control level within 6-8 $\mathrm{min}$ (Fig. $1 C$ ). There was no change in respiratory frequency with 1S,3R-ACPD application to the spinal cord.

1S,3R-ACPD effects were blocked by MCPG, a competitive mGluR antagonist (Eaton et al., 1993; Jane et al., 1993). After MCPG addition to the spinal cord bath $(>7 \mathrm{~min})$, the effect of local application of 1S,3R-ACPD was attenuated, albeit at high concentrations of MCPG. At concentrations $\geq 800 \mu \mathrm{M}$ (bath), MCPG fully blocked the effect of $200 \mu \mathrm{M}$ 1S,3R-ACPD (local) on inspiratory discharges in $\mathrm{C}_{4}$ root (Fig. 2). Tonic activity in the $\mathrm{C}_{4}$ root appeared at higher concentrations of 1S,3R-ACPD $(>1 \mathrm{~mm}$, local). Interestingly, with the same concentration of MCPG in the bath, 1S,3R-ACPD at high concentration (0.8-1.0 mM, local) produced some degree of reduction of inspiratory discharges in the $\mathrm{C}_{4}$ root (data not shown). 

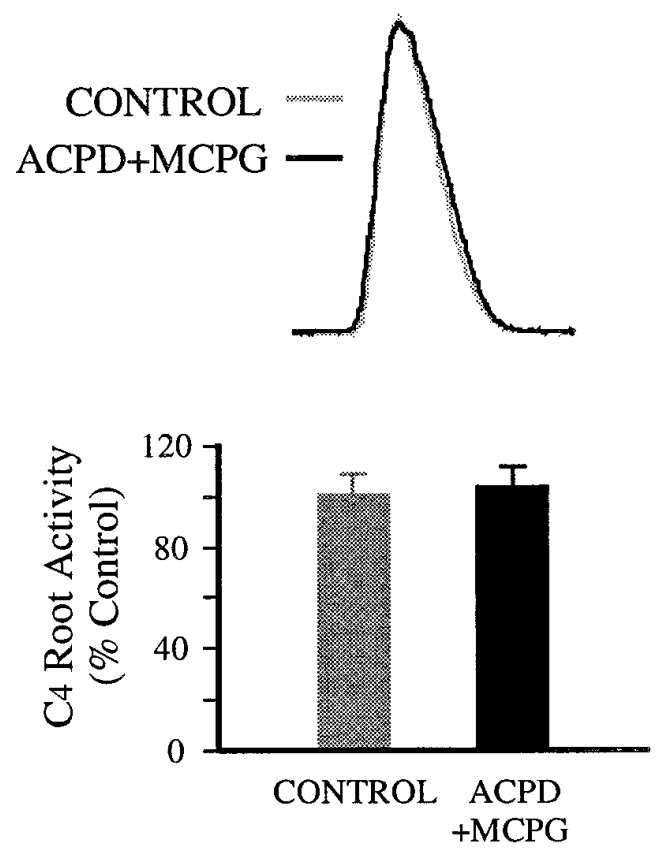

Figure 2. Block of 1S,3R-ACPD effects by mGluR antagonist MCPG. Top, Inspiratory discharges of $\mathrm{C}_{4}$ root are not significantly affected by locally applied 1S,3R-ACPD $(200 \mu \mathrm{M})$ in the presence of MCPG $(800 \mu \mathrm{M}$, bath). Each trace is the average of 10 integrated inspiratory discharges. Bottom, Summary of MCPG (800 $\mu \mathrm{M}$, bath) effect on 1S,3R-ACPD (200 $\mu \mathrm{M}$, local) action from seven preparations. Vertical bars, SEM.

\section{S,3R-ACPD increased excitability of PMNs}

To examine the cellular events underlying changes in $\mathrm{C}_{4}$ root activity induced by $1 \mathrm{~S}, 3 \mathrm{R}-\mathrm{ACPD}$, whole-cell patch-clamp recordings were made from PMNs $(n=6)$ in current-clamp mode. PMNs display spontaneous periodic membrane depolarizations and associated spiking during the inspiratory phase of respiratory cycle in synchrony with bursting activity on the $\mathrm{C}_{4}$ ventral root (Fig. 3A) (Liu et al., 1990). The number of action potentials ranged from 1 to $>12$ per inspiratory phase between neurons, consistent with previous observations (Lindsay and Feldman, 1993).

Local application of 1S,3R-ACPD $(200 \mu \mathrm{M})$ depolarized PMNs by $11 \pm 5 \mathrm{mV}(n=6)$ and produced an increase in the number of action potentials during the inspiratory phase (5/6 cells) (Fig. $3 A$ ). The magnitude of the 1S,3R-ACPD effect on firing varied among PMNs as a function of their firing behaviors. In general, 1S,3RACPD caused a greater increase in both number of spikes and firing frequency on those motoneurons that fired fewer action potentials and/or on those with lower frequency in control conditions. The motoneurons with more action potentials and/or with higher frequency were less affected, even unchanged. The frequency of inspiratory-modulated firing after 1S,3R-ACPD application ranged from 10 to $27 \mathrm{~Hz}$ (mean, $18 \pm 7 \mathrm{~Hz} ; n=5$ ), compared with $2-20 \mathrm{~Hz}$ (mean, $10 \pm 9 \mathrm{~Hz} ; n=6$ ) under control conditions. Both changes in membrane potential and inspiratory firing frequency were significant. At concentrations $>500 \mu \mathrm{M}$, locally applied 1S,3R-ACPD caused tonic firing of action potentials during the expiratory phase (data not shown).

The increase in PMN excitability by $1 \mathrm{~S}, 3 \mathrm{R}-\mathrm{ACPD}$ was also indicated by enhanced repetitive firing in response to current pulses injected during the expiratory phase. In the presence of 1S,3R-ACPD, the number of evoked spikes increased $(6 / 6$ cells) (Fig. 3B).

\section{Differential actions of 1S,3R-ACPD on inspiratory- modulated synaptic current and baseline membrane current of PMNs}

To elucidate the mechanisms underlying the change in cell excitability induced by 1S,3R-ACPD, the effects of 1S,3R-ACPD on membrane currents of PMNs were examined under voltage-clamp conditions $(n=29)$. PMNs exhibit large, fast-rising and slowdeclining inspiratory-modulated inward currents (Fig. 4A,D) (Liu et al., 1990). In each cell, 1S,3R-ACPD (50-500 $\mu \mathrm{M}$, local) caused a decrease in this current when the membrane potentials were clamped at the end-expiratory potentials $(-60$ to $-75 \mathrm{mV}$ ) (Fig. $4 A-C)$. With local application of 1S,3R-ACPD $(200 \mu \mathrm{M})$, peak current and charge transfer (integrated area under the current envelope) of inspiratory drive significantly decreased to $73 \pm 7 \%$ and $70 \pm 5 \%(n=8)$ of control, respectively. The time course for onset and recovery of $1 \mathrm{~S}, 3 \mathrm{R}-\mathrm{ACPD}$ action on PMN synaptic current was similar to that for $\mathrm{C}_{4}$ root activity, but the maximal effect occurred sooner ( $<1 \mathrm{~min}$ ) (Fig. $4 C$ ).

Concurrent with the decrease in inspiratory current, a tonic inward current $\left(I_{\text {acpd }}\right)$ (50-200 pA) was produced by $1 \mathrm{~S}, 3 \mathrm{R}$ ACPD (50-500 $\mu \mathrm{M}$, local) (Fig. $4 A$ ), accompanied by an increase of baseline noise (Figs. $4 A, 5 A, B)$.

The effects of $1 \mathrm{~S}, 3 \mathrm{R}$-ACPD were blocked by the antagonist MCPG (Fig. $4 D-F$ ). The reduction of peak inspiratory current induced by $200 \mu \mathrm{M}$ 1S,3R-ACPD (local) was $8 \pm 5 \%(n=6)$ in the presence of MCPG (5 mM, local) (Fig. $4 F$ ), compared with a $\sim 30 \%$ reduction induced by $1 \mathrm{~S}, 3 \mathrm{R}-\mathrm{ACPD}$ alone (Fig. $4 A-C$ ). No detectable inward current was induced by 1S,3R-ACPD $(200 \mu \mathrm{M}$, local) in the presence of MCPG (5 mM, local) (Fig. $4 D$ ).

To determine whether $I_{\text {acpd }}$ and the accompanying baseline noise increase resulted from a direct postsynaptic action on PMNs or from an increase of synaptic activity, 1S,3R-ACPD was applied after blockage of voltage-dependent $\mathrm{Na}^{+}$currents with TTX (1 $\mu \mathrm{M})$. 1S,3R-ACPD continued to produce inward current (17/17 neurons) (Fig. 5A) and elevated baseline noise. Furthermore, these effects were maintained with a $\mathrm{Ca}^{2+}$-free, high- $\mathrm{Mg}^{2+}(2.5$ $\mathrm{mM})$ bath solution that inhibits chemical synaptic transmission ( $n=2$; not shown).

1S,3R-ACPD at high concentrations can activate ionotropic glutamate receptors (Schoepp et al., 1990). To identify the receptors transducing the inward current, 1S,3R-ACPD was applied in the presence of ionotropic glutamate receptor antagonists added to the bathing solution; an inward current persisted after concurrent CNQX $(100 \mu \mathrm{M})$ and MK-801 $(250 \mu \mathrm{M})$ application $(n=3)$ (Fig. 5B).

The membrane $I-V$ relationship was examined before and after 1S,3R-ACPD application (Fig. 5C). The $I-V$ relationship for the 1S,3R-ACPD-induced inward current (Fig. 5E) was obtained by subtracting the $I-V$ relationship during $1 \mathrm{~S}, 3 \mathrm{R}-$ ACPD treatment from that obtained under control conditions (Fig. 5D). The $I_{\text {acpd }}$ decreased linearly with hyperpolarizing potentials (Fig. $5 E$ ). A reversal potential of $-102 \pm 6 \mathrm{mV}$ for $I_{\text {acpd }}$ was demonstrated in 7 of 12 PMNs within the testing voltage range $(-40$ to $-120 \mathrm{mV})$. The $I-V$ relationships also revealed a decrease in input conductance during 1S,3R-ACPD treatment, indicated by the reduced slope of the $I-V$ curve (Fig. $5 D)$. The membrane input resistance at resting potential $(-60$ to $-75 \mathrm{mV})$ increased to $138 \pm 7 \%$ of control $(n=7)$. In the other five cells, $I_{\text {acpd }}$ did not reverse within the tested voltage range. The membrane input resistance in these cells was also increased, but to a lesser degree $(125 \pm 11 \%, n=5)$. 

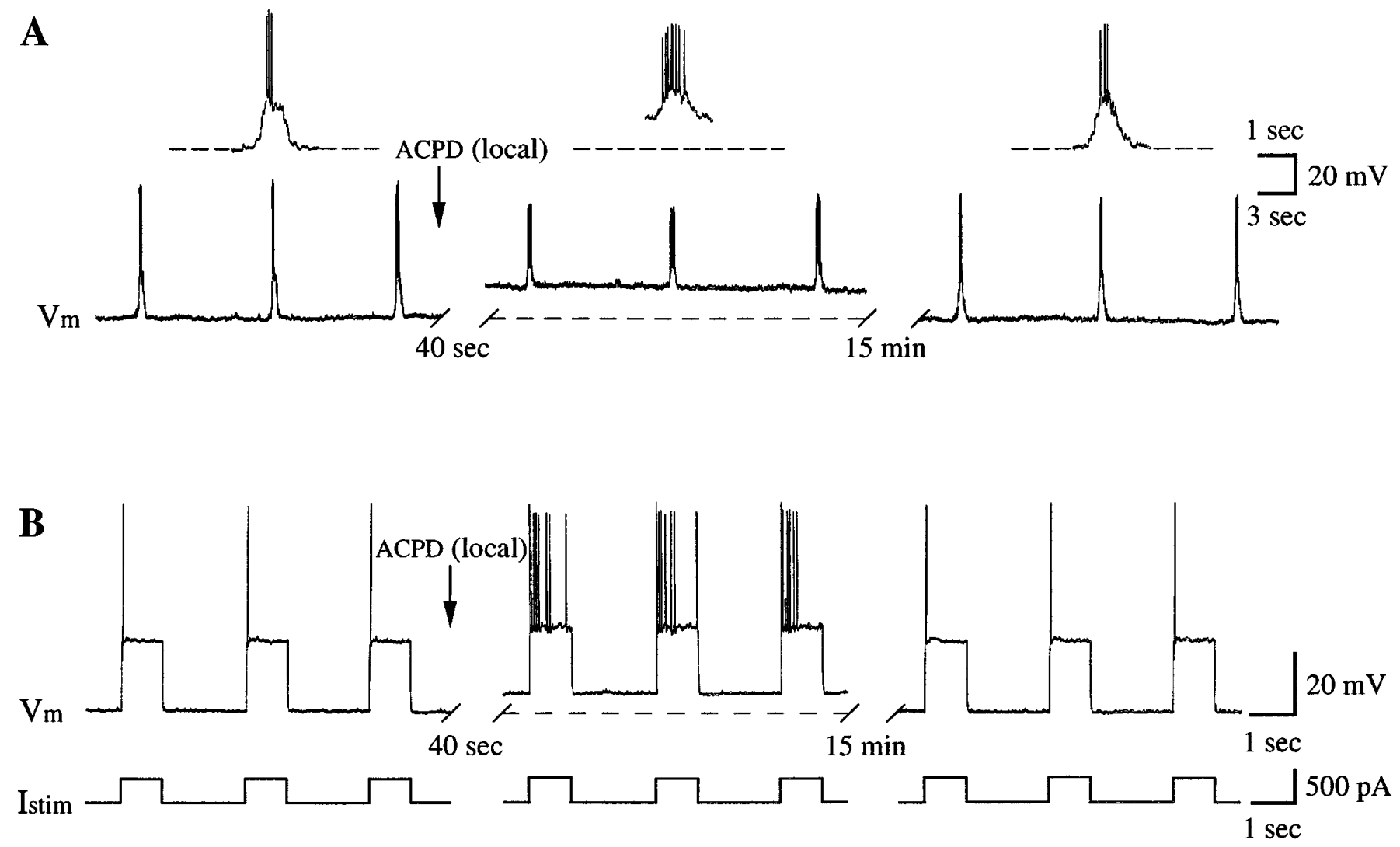

Figure 3. Increase of excitability of PMNs by $1 \mathrm{~S}, 3 \mathrm{R}-\mathrm{ACPD}$. $A, 1 \mathrm{~S}, 3 \mathrm{R}-\mathrm{ACPD}$ (200 $\mu \mathrm{M}$, local) depolarized PMNs and increased the number of action potentials during the inspiratory phase. The insets are traces with expanded time scale. $V_{\mathrm{m}}$, Membrane potential recorded under current-clamp conditions. $B, 1 \mathrm{~S}, 3 \mathrm{R}$-ACPD enhanced repetitive firing of the PMN in response to injected current pulses $\left(I_{\text {stim }} ; 0.4 \mathrm{nA}, 1 \mathrm{sec} ;\right.$ bottom trace $)$ during the expiratory phase. Dotted lines indicate baseline under control conditions. Resting (end-expiratory) membrane potential, $-68 \mathrm{mV}$.

\section{Presynaptic action of 1S,3R-ACPD is responsible for reduction of synaptic current}

To investigate the mechanisms underlying 1S,3R-ACPD-induced decrease in synaptic current, we examined the effect of $1 \mathrm{~S}, 3 \mathrm{R}$ ACPD on the amplitude and frequency of mEPSCs. After treatment with TTX (1 $\mu \mathrm{M}$, bath), PMNs exhibit spontaneous mEPSCs (Liu and Feldman, 1992; Dong and Feldman, 1995) (Fig. 6 A). These events were collected from a $20-25$ min control period and then during drug application (25-30 min). The mEPSC peak amplitude and the time interval between successive EPSCs were used to construct cumulative amplitude and interval histograms (Fig. 6B,C).

1S,3R-ACPD (50 $\mu \mathrm{M}$, bath) caused a significant decrease in the mean frequency of mEPSCs $(n=5 ; 31 \pm 12 \%$; $p<0.05)$ (Fig. $6 D)$. An example of the cumulative interval histograms showing the decrease of EPSC frequency is given in Figure $6 B$. The decrease is indicated by the shift of the interval histogram under 1S,3R-ACPD condition toward longer values compared with the control histogram. In contrast, the amplitude of mEPSCs was not altered significantly ( $96 \pm 8 \%$ of control value) by 1 S,3R-ACPD (Fig. 6D). Figure $6 C$ shows unshifted cumulative amplitude histograms.

The lack of action of 1S,3R-ACPD on AMPA receptors was confirmed. Our previous studies indicate that the transmission of excitatory inspiratory drive from bulbospinal inspiratory neurons to PMNs is mediated by an EAA (McCrimmon et al., 1989; Liu et al., 1990) acting principally at postsynaptic non-NMDA receptors (Liu et al., 1990; Feldman and Smith, 1994). Therefore, AMPA was used to elicit membrane current in PMNs isolated by TTX. Brief local application (1 sec) of $50 \mu \mathrm{M}$ AMPA produced an inward current with peak amplitude $300-500 \mathrm{pA}(n=4)$. This AMPA-induced current was unaffected by $1 \mathrm{~S}, 3 \mathrm{R}-\mathrm{ACPD}(50 \mu \mathrm{M}$, bath), with its magnitude at $95 \pm 8 \%(n=4)$ of control value (Fig. $6 E, F)$.

\section{Ionic basis of 1S,3R-ACPD-induced inward current}

Our findings suggest a $\mathrm{K}^{+}$conductance as the principal source of the 1S,3R-ACPD-induced inward current. First, $I_{\text {acpd }}$ has a reversal potential close to the estimated $\mathrm{K}^{+}$equilibrium potential $\left(E_{\mathrm{K}^{+}}\right)$. Second, $I_{\text {acpd }}$ decreased with hyperpolarizing potentials, presumably by virtue of the reduced driving force for $\mathrm{K}^{+}$at potentials closer to $E_{\mathrm{K}^{+}}$. Third, $I_{\text {acpd }}$ was associated with a decrease in conductance. We further examined the involvement of $\mathrm{K}^{+}$conductances in the induction of $I_{\text {acpd }}$ by testing the effect of changing extracellular $\left[\mathrm{K}^{+}\right]$on the reversal potential of $I_{\text {acpd }}$. The same protocol (compare Fig. $5 C-E$ ) was used to determine the $I-V$ relations for $I_{\text {acpd }}$ in a normal perfusion solution $\left(3 \mathrm{mM} \mathrm{K}^{+}\right)$ and in a perfusion solution with raised $\left[\mathrm{K}^{+}\right](9 \mathrm{~mm})$. In $3 \mathrm{~mm} \mathrm{~K}^{+}$ solution $(n=4), I_{\text {acpd }}$ reversed at a membrane potential of $-101 \pm 5 \mathrm{mV}$. When extracellular $\left[\mathrm{K}^{+}\right]$raised to $9 \mathrm{~mm}, I_{\text {acpd }}$ reversed at $-75 \pm 7 \mathrm{mV}$, a $26 \mathrm{mV}$ depolarizing shift (Fig. 7). Both reversal potentials of $I_{\text {acpd }}$ are close but slightly hyperpolarized to the estimated $E_{\mathrm{K}^{+}}$(approximately $-95 \mathrm{mV}$ with $3 \mathrm{~mm}\left[\mathrm{~K}^{+}\right]_{\mathrm{o}}$ and $-66 \mathrm{mV}$ with $9 \mathrm{~mm}\left[\mathrm{~K}^{+}\right]_{\mathrm{o}}$ ) under our experimental conditions.

We also tested the effects of $\mathrm{K}^{+}$channel blockers. $\mathrm{Ba}^{2+}$ inhibits various $\mathrm{K}^{+}$currents, including $\mathrm{K}^{+}$leak currents (Jones, 1989; Hille, 1992). Numerous pharmacological manipulations (Bayliss 
A CONTROL $\quad \operatorname{ACPD}(200 \mu \mathrm{M}$, local $)$

RECOVERY

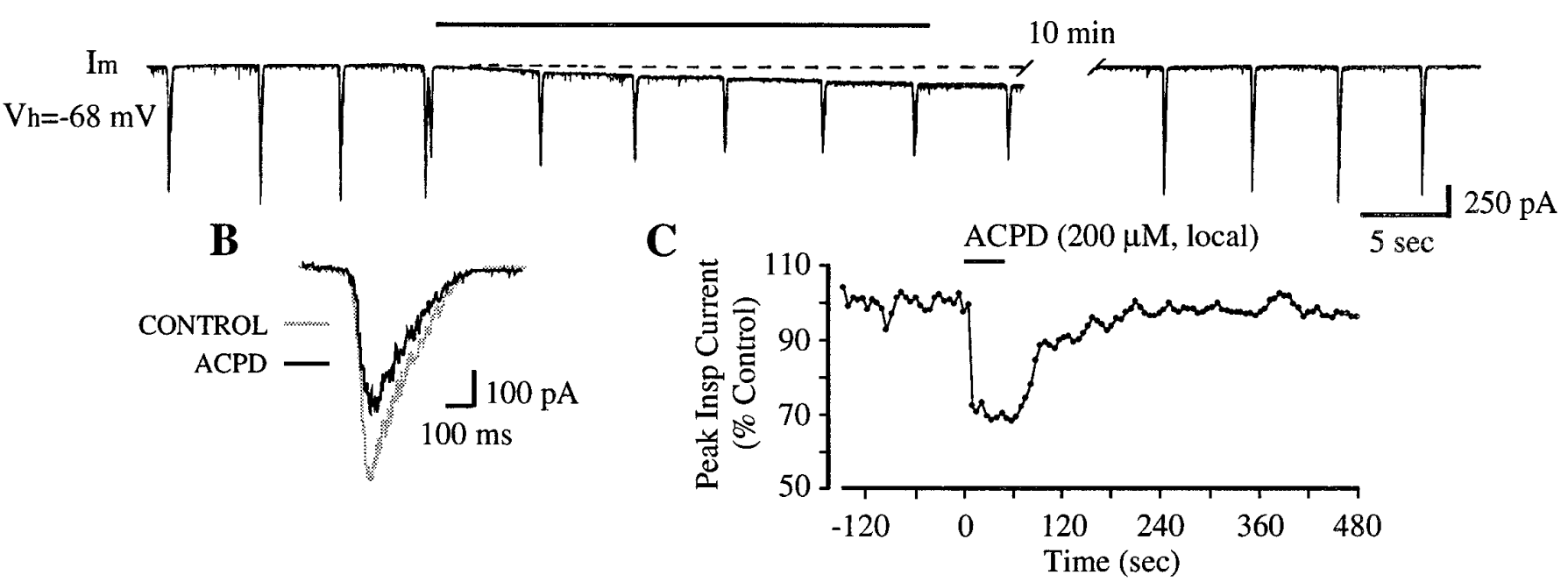

D $\quad$ MCPG $(5 \mathrm{mM}$, local $) \quad$ ACPD $(200 \mu \mathrm{M}$, local $)$
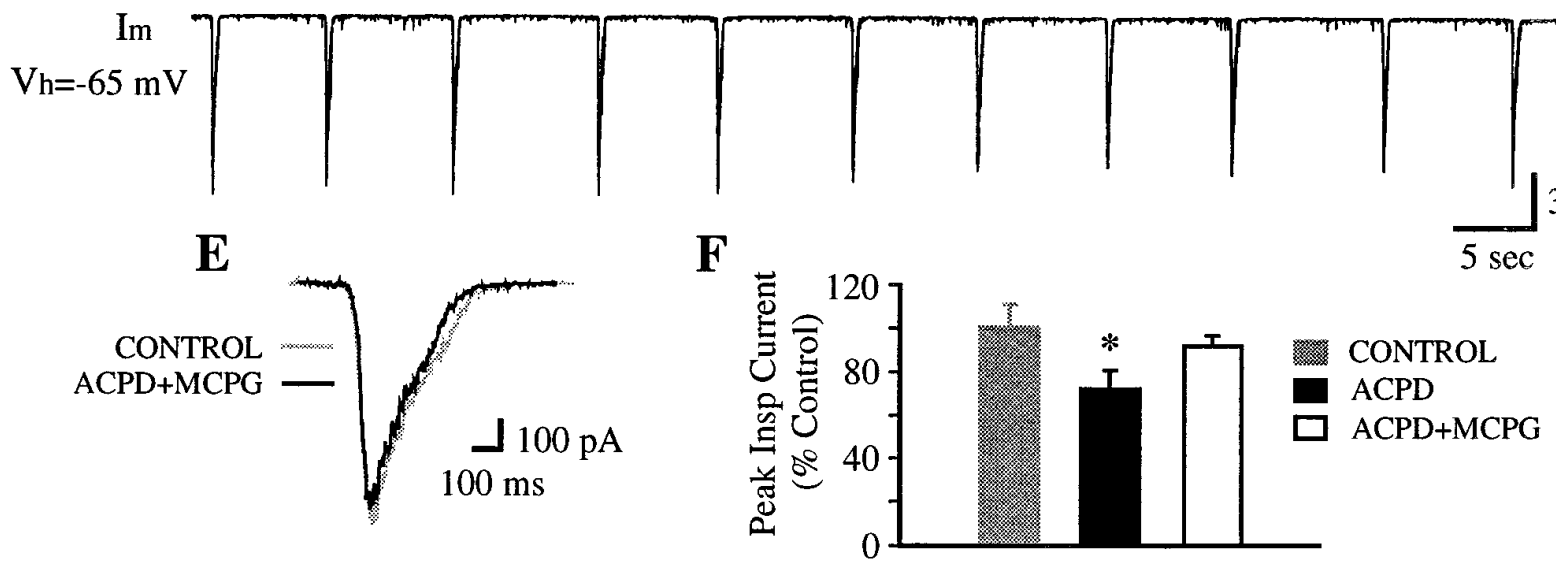

Figure 4. Differential effects of mGluR activation by 1S,3R-ACPD on inspiratory synaptic current and baseline membrane current of PMNs. $A$, Local application of 1S,3R-ACPD $(200 \mu \mathrm{M})$ decreased inspiratory-modulated synaptic current and induced an inward current when PMN was voltage-clamped at the end-expiratory potential $\left(V_{\mathrm{h}}\right)$ of $-68 \mathrm{mV} . B$, Reduction of inspiratory-modulated synaptic current ( $\sim 70 \%$ of control) at $30 \mathrm{sec}$ after $1 \mathrm{~S}, 3 \mathrm{R}-\mathrm{ACPD}$ (200 $\mu \mathrm{M}$, local). $C$. Time course of inspiratory current in response to 1S,3R-ACPD (200 $\mu \mathrm{M}$, local). Peak inspiratory current is expressed as the percentage of control value. D, E, MCPG blocked 1S,3R-ACPD effects on both synaptic currents and baseline membrane current. Local application of MCPG (5 $\mathrm{mm}$ ) began $5 \mathrm{~min}$ before 1S,3R-ACPD (200 $\mu \mathrm{M}$, local) application and continued during the course of 1S,3R-ACPD test. $F$, Summary of effects of 1S,3R-ACPD (200 $\mu \mathrm{M}$, local) on peak inspiratory-modulated synaptic currents with $(n=8)$ and without $(n=6)$ concurrent application of MCPG $(5$ mM, local). Vertical bars, SEM; asterisk, significant difference ( $p<0.05 ; t$ test) from control values. Superimposed traces in $B$ and $E$ are the average of six consecutive inspiratory-modulated synaptic currents before and after drug application.

et al., 1992; Fisher and Nistri, 1993; Guérineau et al., 1995), including application of mGluR agonists (Charpak et al., 1990; Glaum and Miller, 1992; Guérineau et al., 1994, 1995), affect $\mathrm{Ba}^{2+}$-sensitive $\mathrm{K}^{+}$leak currents. We examined the possibility that blockage of a $\mathrm{K}^{+}$conductance underlies $I_{\text {acpd }}$ by testing (1) whether $\mathrm{Ba}^{2+}$ induces an inward current similar to $I_{\text {acpd }}$ and (2) whether $\mathrm{Ba}^{2+}$ affects $I_{\text {acpd }}$.

$\mathrm{Ba}^{2+}$ (2 mM, bath) produced a persistent inward current (voltage-clamp) or depolarization (current-clamp). This was accompanied by a remarkable decrease in membrane conductance (Fig. 8A). Hyperpolarizing voltage steps from the end-expiratory potential $(-70 \mathrm{mV})$ to $-130 \mathrm{mV}$ were used to generate $I-V$ plots. A substantial increase $(187 \pm 12 \%, n=4)$ in input resistance by $\mathrm{Ba}^{2+}$ was apparent, indicated by the decreased slope of $I-V$ plot
(Fig. $8 A$ ). The $I-V$ relationship of the $\mathrm{Ba}^{2+}$-induced inward current $\left(I_{\mathrm{Ba}}\right)$ indicated that this current decreased with hyperpolarization and reversed at $V_{\mathrm{m}}$ approximately $-93 \pm 5 \mathrm{mV}(n=4)$ (Fig. $8 B$ ), which is close to the presumed $E_{\mathrm{K}^{+}}$.

In the presence of $\mathrm{Ba}^{2+}, 1 \mathrm{~S}, 3 \mathrm{R}-\mathrm{ACPD}$ still induced some inward current $(32 \pm 8 \mathrm{pA}, n=3)$ near resting membrane potentials $(-60$ to $-70 \mathrm{mV})$, but the magnitude of $I_{\text {acpd }}$ was reduced in half $(71 \pm 11 \mathrm{pA}, n=3$ ) (Fig. $8 C, D)$. $\mathrm{Ba}^{2+}$ also attenuated the increase in input resistance by $1 \mathrm{~S}, 3 \mathrm{R}-\mathrm{ACPD}(12 \pm$ $6 \%, n=3)$, compared with a $38 \%$ increase in the absence of $\mathrm{Ba}^{2+}$. The $I-V$ relationship of the $\mathrm{Ba}^{2+}$-sensitive component of $I_{\text {acpd }}$ (Fig. $8 E$ ), obtained by subtracting $I_{\text {acpd }}$ without $\mathrm{Ba}^{2+}$ from that with $\mathrm{Ba}^{2+}$, had characteristics similar to those of $I_{\mathrm{Ba}}$. This current reversed at approximately $-92 \mathrm{mV}$, very near the estimated $E_{\mathrm{K}^{+}}$. 
A

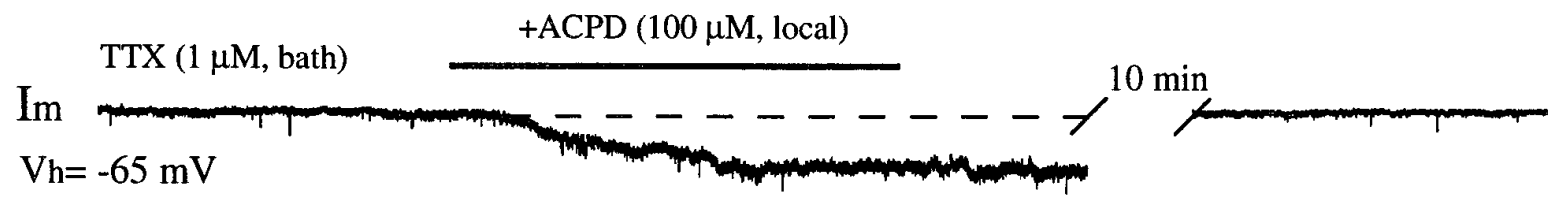

B

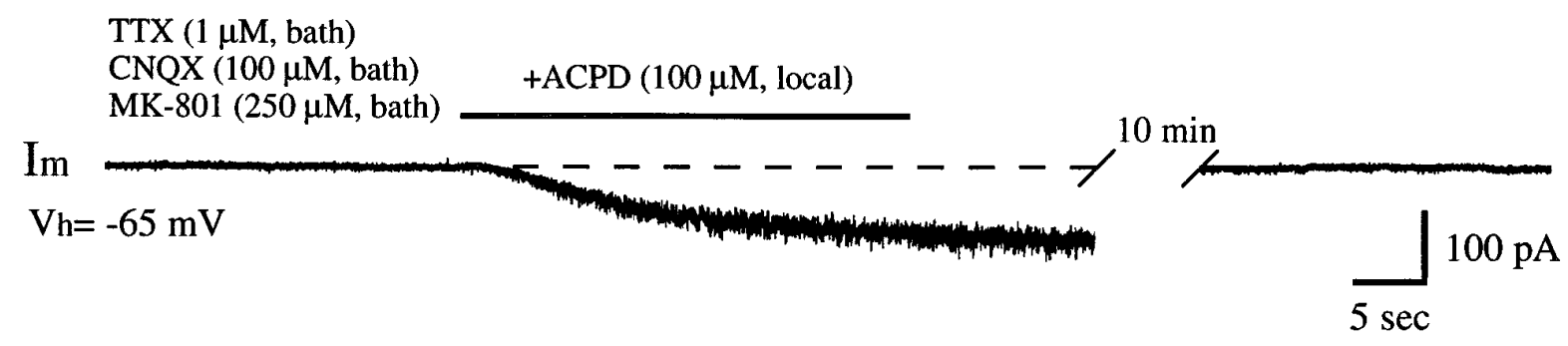

$\mathbf{C}$

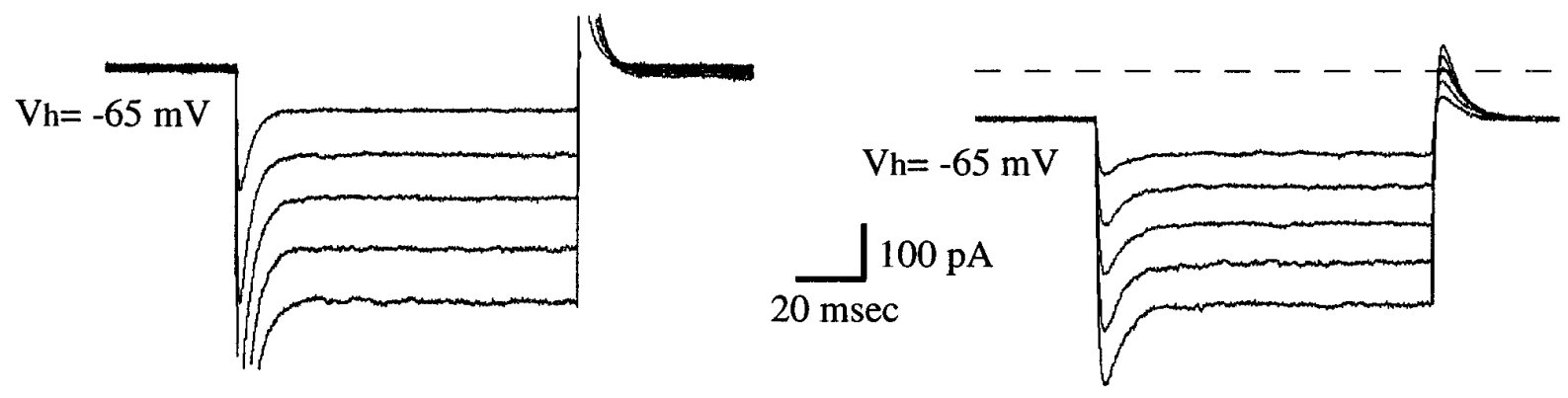

$\mathbf{D}$

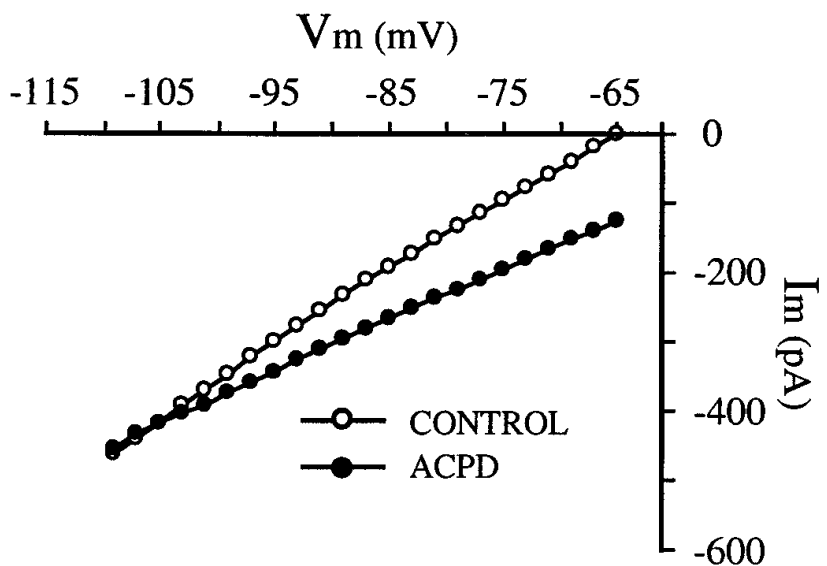

$\mathbf{E}$

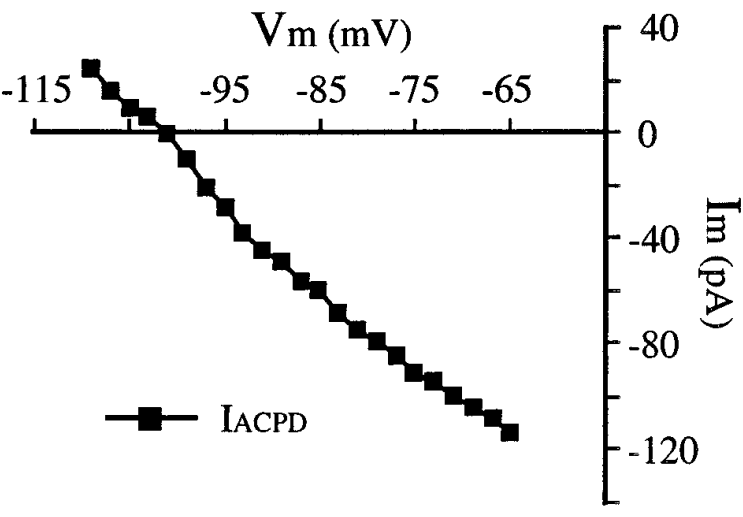

Figure 5. Characteristics of 1S,3R-ACPD-induced inward current. $A, B$, Raw traces showing the persistence of 1S,3R-ACPD-induced inward current after TTX treatment $(1 \mu \mathrm{M}$, bath; $A, B)$ and with ionotropic glutamate receptor antagonists CNQX (100 $\mu \mathrm{M}$, bath) and MK-801 (250 $\mu \mathrm{M}$, bath; $B)$. $C$, Raw traces of current responses to a series of command voltage pulses. Pulse step size, $2 \mathrm{mV}$ (only every fifth trace is shown here); pulse width, $100 \mathrm{msec}$; pulse frequency, $2 \mathrm{~Hz}$. These experiments were performed in the presence of TTX $(1 \mu \mathrm{M}, \mathrm{bath}) . D$, Membrane $I-V$ relationship before and after application of 1S,3R-ACPD $(200 \mu \mathrm{M}$, local). I- $V$ curve was obtained by plotting current change (averaged steady-state current values at 5-10 msec before offset of voltage step) against membrane potentials. Note that membrane input resistance increased in 1S,3R-ACPD condition as indicated by the reduced slope of the $I-V$ plot. $E, I-V$ relationship for the $1 \mathrm{~S}, 3 \mathrm{R}-\mathrm{ACPD}$-induced inward current. This $I-V$ plot was obtained by subtracting the $I-V$ relationship during 1S,3R-ACPD treatment from that in control condition (with $1 \mu \mathrm{M}$ TTX). Dotted line, The level of baseline current $\left(I_{\mathrm{m}}=0\right)$ under control conditions.

On the other hand, the residual $\mathrm{Ba}^{2+}$-resistant component of $I_{\text {acpd }}$ had a different $I-V$ relationship curve (Fig. $8 E$ ). It did not reverse within the test-voltage range.

\section{DISCUSSION}

Activation of mGluRs by 1S,3R-ACPD modulates endogenous synaptic transmission and postsynaptic membrane properties of
PMNs. The actions induced by 1 S,3R-ACPD are multiple, including presynaptic inhibition of synaptic transmission and an increase in postsynaptic membrane excitability via a mechanism involving depolarization and/or generation of inward current, associated with a decrease in membrane conductance. The net result of these differential actions of generic activation of mGluRs on PMNs (under our experimental conditions) is a decrease at low concen- 
A

\section{CONTROL}

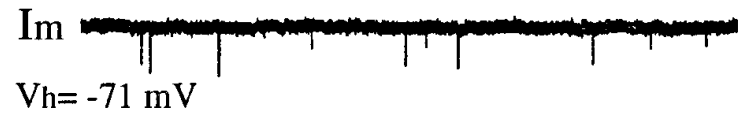

ACPD (50 $\mu \mathrm{M}$, bath)

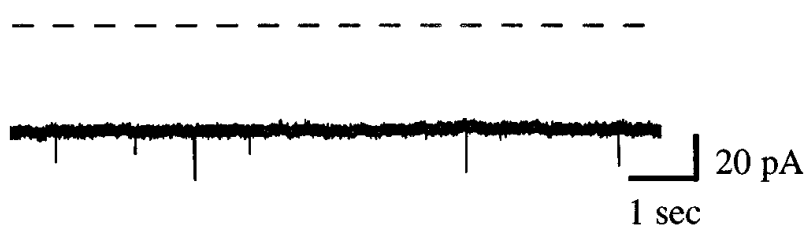

B

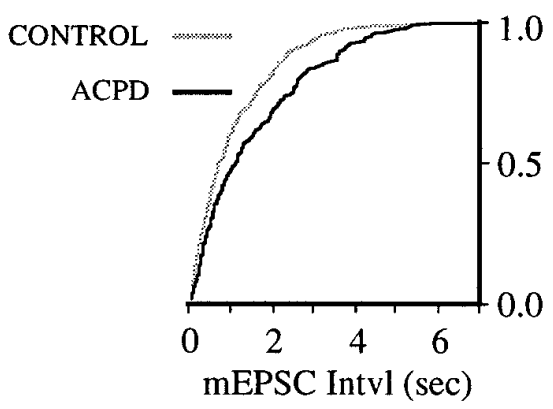

C

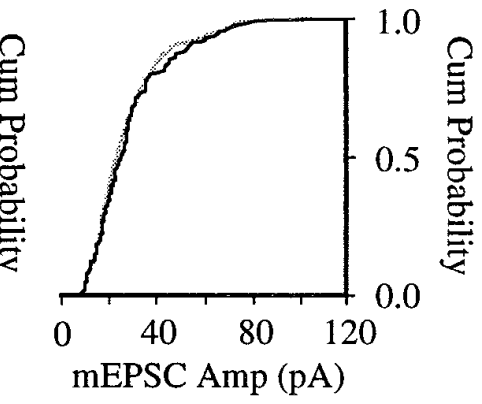

D
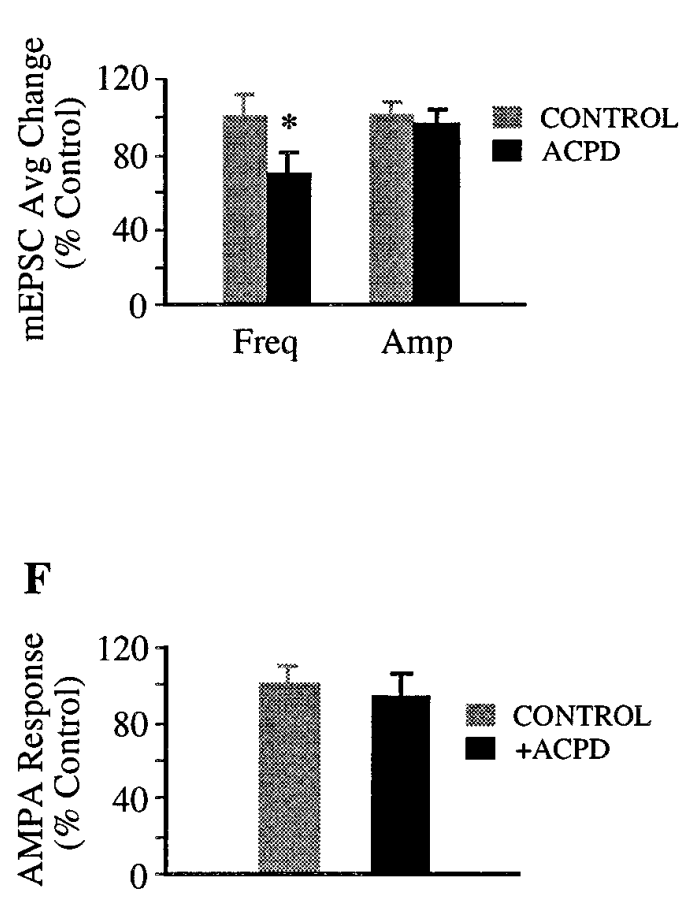

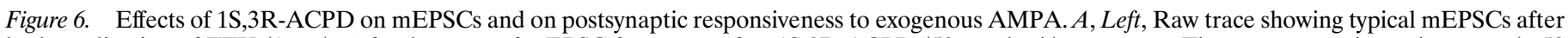

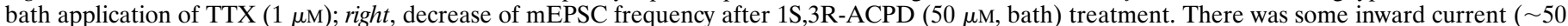

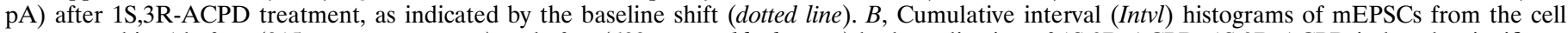

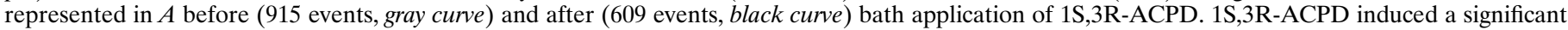

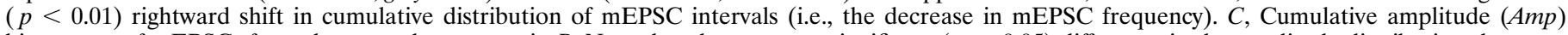

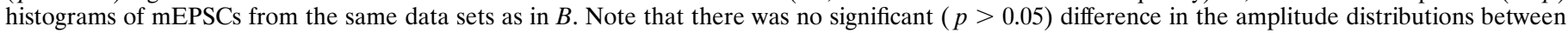

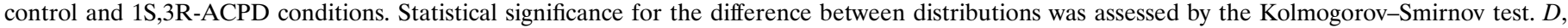

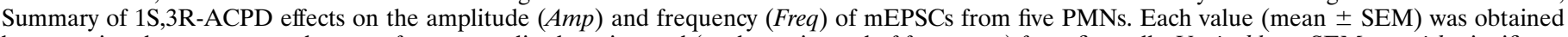

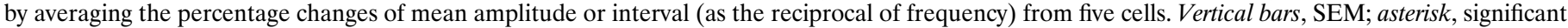

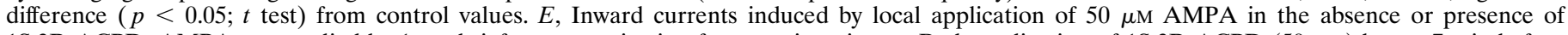

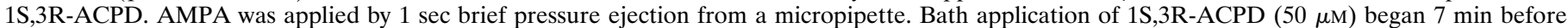

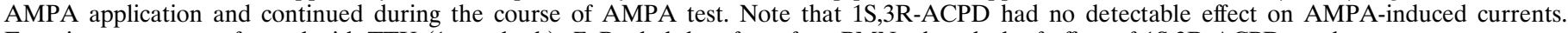

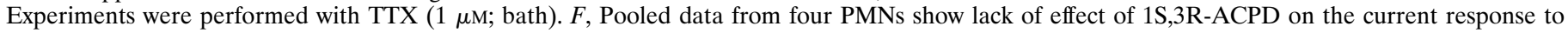
exogenous AMPA.

trations and an increase at higher concentrations in inspiratorymodulated motor output.

\section{Presynaptic action of 1S,3R-ACPD underlies depression of synaptic current}

1S,3R-ACPD decreased the amplitude of inspiratory-modulated synaptic currents in PMNs. The inspiratory-modulated synaptic current is composed of many unitary EPSCs. Changes in either the amplitude or the frequency of unitary EPSCs could produce this change of inspiratory synaptic current. We assumed that changes in mEPSC amplitude could be caused by postsynaptic actions of test drugs, whereas changes in mEPSC frequency are solely the consequence of presynaptic actions (Fatt and Katz, 1952; Redman, 1990; Kullmann and Siegelbaum, 1995). Several lines of evidence suggest that the 1S,3R-ACPD-induced reduction of inspiratory current is mediated by mGluRs located on the presynaptic terminals of bulbospinal inspiratory neurons onto PMNs.

First, because neither mEPSC amplitude nor response to exogenous AMPA was changed by $1 \mathrm{~S}, 3 \mathrm{R}-\mathrm{ACPD}$, the postsynaptic membrane sensitivity to the endogenous transmitter was likely unaffected. Transmission of inspiratory drive from bulbospinal neurons to PMNs is mediated by an EAA acting primarily at non-NMDA receptors (Liu et al., 1990). We presume that the response to exogenously applied AMPA represents activation of a superset of AMPA receptors, including those that mediate the synaptically generated AMPA component of the EPSCs. Thus, if the decrease of synaptic current was attributable to 1S,3R-ACPD reducing the sensitivity of postsynaptic EAA receptors, both the 


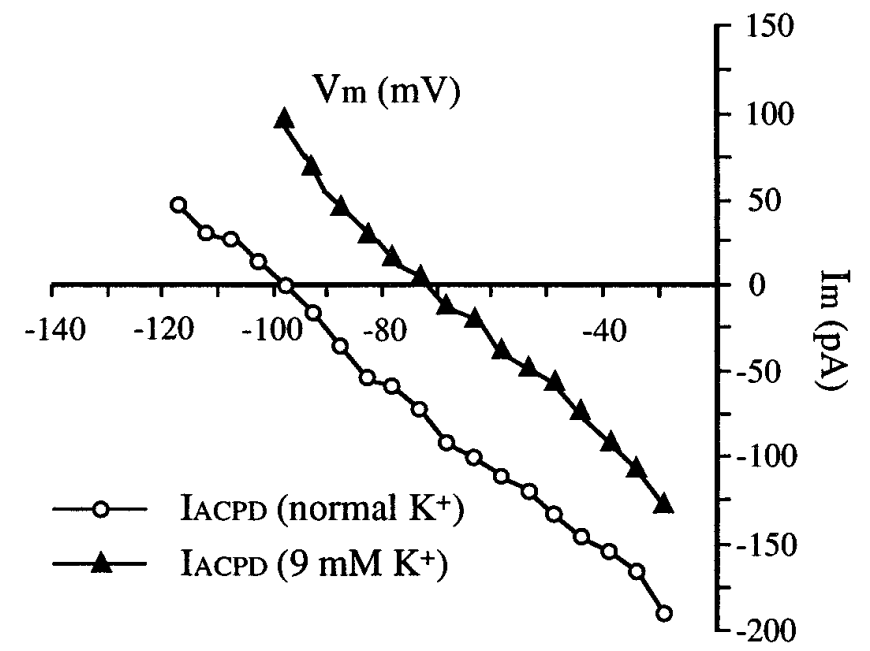

Figure 7. A shift of reversal potential of 1S,3R-ACPD-induced inward current $\left(I_{A C P D}\right)$ by changing of extracellular $\left[\mathrm{K}^{+}\right]$. The $I-V$ relationships for the $I_{\text {acpd }}$ in perfusion solutions with normal $\left[\mathrm{K}^{+}\right](3 \mathrm{mM})$ and elevated $\left[\mathrm{K}^{+}\right](9 \mathrm{mM})$ were determined using the same protocol (but voltage step size $=5 \mathrm{mV}$ ) described in Figure 5. Tests were performed in the presence of TTX (1 $\mu \mathrm{M}$; bath).

amplitude of mEPSCs and the current induced by AMPA should have been reduced by $1 \mathrm{~S}, 3 \mathrm{R}-\mathrm{ACPD}$. Our observations to the contrary suggest that the $1 \mathrm{~S}, 3 \mathrm{R}-\mathrm{ACPD}$ depression of synaptic current was not the result of a postsynaptic action on ionotropic glutamate receptors.

Second, 1S,3R-ACPD reduced the mEPSC frequency. Because mEPSC frequency is dependent on transmitter release probability (Fatt and Katz, 1952; Redman, 1990), its reduction indicates a presynaptic site of action. Thus, 1S,3R-ACPD decreases transmitter release from bulbospinal presynaptic terminals on PMNs. We recognize that a change in the behavior of hypothesized silent synapses might contribute to a change of mEPSC frequency (Kullmann, 1994; Isaac et al., 1995; Kullmann and Siegelbaum, 1995; Liao et al., 1995). If 1S,3R-ACPD acted via change in silent synapses, we would expect to (but did not) see a decrease in amplitude of both mEPSCs and the current response to exogenous AMPA (attributable to reduction of available postsynaptic AMPA receptors).

The mechanisms underlying the presynaptic action of $1 \mathrm{~S}, 3 \mathrm{R}-$ ACPD are not known. Inhibition of transmitter release from presynaptic terminals may result from the reduction of presynaptic $\mathrm{Ca}^{2+}$ influx directly or indirectly via channels (i.e., $\mathrm{K}^{+}$or $\mathrm{Na}^{+}$ channels) determining action potential duration (Nicoll et al., 1990). Inhibition of voltage-dependent $\mathrm{Ca}^{2+}$ currents after mGluR activation occurs in neuronal soma (Lester and Jahr, 1990; Sayer et al., 1992; Trombley and Westbrook, 1992; Swartz et al., 1993; Chio and Lovinger, 1996). Whether a similar mechanism underlies the presynaptic inhibitory action of the mGluR agonists is unknown. In support of this hypothetical mechanism, the effects of mGluR activation on both $\mathrm{Ca}^{2+}$ currents and synaptic transmission seem to be coupled by similar second messenger systems (Trombley and Westbrook, 1992; Swartz et al., 1993; Stefani et al., 1994). Moreover, the inhibitory action of $1 \mathrm{~S}, 3 \mathrm{R}-\mathrm{ACPD}$ on synaptic currents is occluded by voltage-dependent $\mathrm{Ca}^{2+}$ channel blockers (Stefani et al., 1994; Glaum and Miller, 1995). Furthermore, reduction of evoked presynaptic $\mathrm{Ca}^{2+}$ influx in the presence of an mGluR agonist is correlated with suppression of EPSPs (Yoshino and Kamiya, 1995). These findings suggest that reduction of $\mathrm{Ca}^{2+}$ influx may underlie the presynaptic action of mGluRs.

Another possible mechanism is direct modulation of the exocytotic machinery influencing the availability of vesicles or their probability of release (Hayashi et al., 1993). We found that 1S,3RACPD was effective in reducing the frequency of spontaneous mEPSCs when presynaptic action potentials were blocked (with TTX), consistent with observations in hippocampal (Maki et al., 1994) and striatal (Tyler and Lovinger, 1995) neurons. These spontaneous mEPSCs seem independent of presynaptic $\mathrm{Ca}^{2+}$ influx, as indicated by their persistence in the presence of $\mathrm{Ca}^{2+}$ channel blockers (Scanziani et al., 1992; Scholz and Miller, 1992). Thus, the inhibition of presynaptic $\mathrm{Ca}^{2+}$ currents does not seem obligatory for the reduction of transmitter release by $1 \mathrm{~S}, 3 \mathrm{R}$ ACPD. 1S,3R-ACPD may inhibit transmitter release by interfering with the secretion cascade subsequent to presynaptic $\mathrm{Ca}^{2+}$ influx. Such a mechanism could also underlie 1S,3R-ACPDinduced inhibition of evoked transmitter release.

\section{Mechanism underlying 1S,3R-ACPD-induced increase in excitability}

1S,3R-ACPD also induced an increase in PMN excitability characterized by enhanced firing in response to either inspiratorymodulated synaptic or injected current. The underlying mechanism involves an inward current with an associated increase in input resistance. The 1S,3R-ACPD-induced current $\left(I_{\mathrm{acpd}}\right)$ reversed at $V_{\mathrm{m}}$ approximately $-100 \mathrm{mV}$, close to the estimated $E_{\mathrm{K}^{+}}$ $(-95 \mathrm{mV})$. Elevating extracellular $\left[\mathrm{K}^{+}\right]$to $9 \mathrm{~mm}$ reduced the $I_{\text {acpd }}$ reversal potential to $-75 \mathrm{mV}$, in the same direction as the $E_{\mathrm{K}^{+}}$ $(-66 \mathrm{mV})$ shift. These findings suggest that blockade of resting $\mathrm{K}^{+}$conductances contributes to $I_{\text {acpd }}$. Consistent with this hypothesis, $\mathrm{Ba}^{2+}$, a K ${ }^{+}$channel blocker, induced an inward current with a reversal potential at $-93 \mathrm{mV}$ and a decrease of membrane conductance; this indicates the presence of $\mathrm{Ba}^{2+}$-sensitive $\mathrm{K}^{+}$ conductances at resting membrane potential. Moreover, $\mathrm{Ba}^{2+}$ greatly reduced $I_{\text {acpd }}$. Similar to the $\mathrm{Ba}^{2+}$-induced inward current, the $\mathrm{Ba}^{2+}$-sensitive component of $I_{\text {acpd }}$ reversed at approximately $-92 \mathrm{mV}$, very near the estimated $E_{\mathrm{K}^{+}}$. On the basis of these findings, we conclude that the dominant component of inward current in response to $1 \mathrm{~S}, 3 \mathrm{R}-\mathrm{ACPD}$ results from the blockade of a $\mathrm{Ba}^{2+}$-sensitive resting $\mathrm{K}^{+}$conductance.

We also found a second component of $I_{\text {acpd }}$ that was resistant to $\mathrm{Ba}^{2+}$. This residual component could not be explained by the incomplete blockage of the $\mathrm{Ba}^{2+}$-sensitive $\mathrm{K}^{+}$conductance, because higher $\left[\mathrm{Ba}^{2+}\right](2-4 \mathrm{~mm})$ failed to decrease $I_{\text {acpd }}$ further, and this component had an $I-V$ relationship totally different from that of the $\mathrm{Ba}^{2+}$-sensitive component of $I_{\text {acpd }}$. We assume that some other conductances are involved in this second component of $I_{\text {acpd }}$. The charge carrier for this component is not clear and remains to be examined. The fact that this current did not reverse within the test-voltage range suggests the involvement of an ion current with an equilibrium potential far from resting potential. Because $I_{\text {acpd }}$ contains this second current, the $I-V$ curve of total $I_{\text {acpd }}$ displays a downward shift relative to that of $\mathrm{Ba}^{2+}$-sensitive current. Accordingly, the reversal potential of $I_{\text {acpd }}$ is more negative (approximately $-100 \mathrm{mV}$ ) than the estimated $E_{\mathrm{K}^{+}}$. This second component might be more profound in the cells showing no reversal potential of $I_{\text {acpd }}$. Thus, the resultant downward shift of the $I-V$ relationship of $I_{\text {acpd }}$ in these cells would be even greater, and consequently the reversal potential shifted beyond the test-voltage range. These cells might belong to a distinct group 

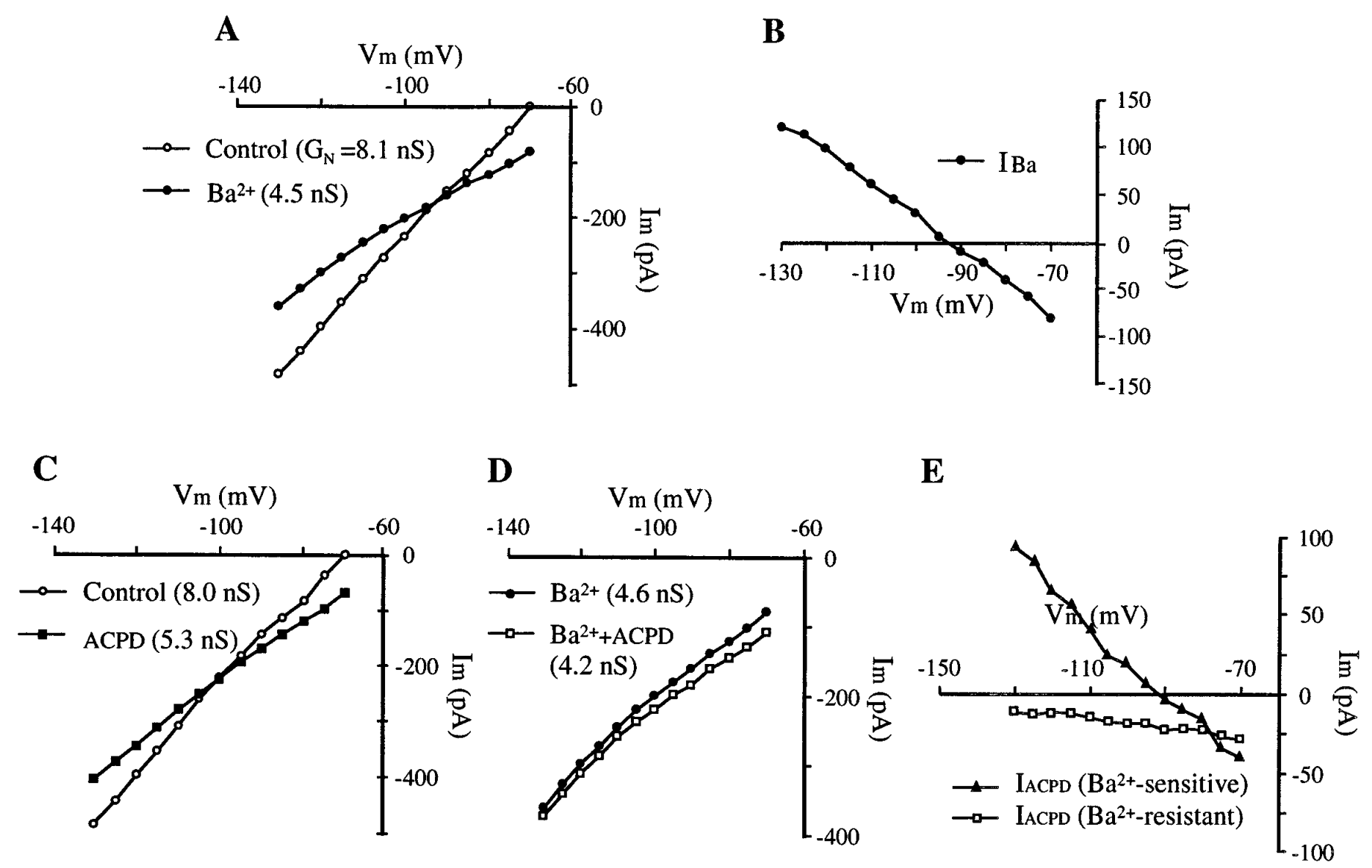

Figure 8. Effects of $\mathrm{Ba}^{2+}$ on membrane properties and on 1S,3R-ACPD-induced inward current. $A$, Membrane $I-V$ relationships before and after perfusion with $\mathrm{Ba}^{2+}(2 \mathrm{mM}) . V_{\mathrm{m}},-70 \mathrm{mV}$. Note that $\mathrm{Ba}^{2+}$ induced an inward current at resting membrane potential $(-70 \mathrm{mV})$ and reduced the slope of the $I-V$ plot. $G_{\mathrm{N}}$, Membrane input conductance. $B, I-V$ relationship for the $\mathrm{Ba}^{2+}$-induced inward current with a reversal potential at approximately $-93 \mathrm{mV}$. $C, D$, Membrane $I-V$ relationships showing the occlusion of $1 \mathrm{~S}, 3 \mathrm{R}-\mathrm{ACPD}$ effect by $\mathrm{Ba}^{2+}$. $1 \mathrm{~S}, 3 \mathrm{R}-\mathrm{ACPD}$ produced an inward current and increased input resistance in the absence of $\mathrm{Ba}^{2+}(C)$. In the presence of $\mathrm{Ba}^{2+}$, the magnitude of inward current and the degree of the increase in input resistance by $1 \mathrm{~S}, 3 \mathrm{R}-\mathrm{ACPD}$ was greatly attenuated $(D) . E, I-V$ plots for $\mathrm{Ba}^{2+}$-sensitive and $\mathrm{Ba}^{2+}$-resistant components of 1S,3R-ACPD-induced current. The $I-V$ plot of $\mathrm{Ba}^{2+}$-sensitive component was obtained by subtracting $I_{\text {acpd }}$ in the absence of $\mathrm{Ba}^{2+}$ from that in the presence of $\mathrm{Ba}^{2+}$. The identical protocols, as described in Figure 5, were used to generate the $I-V$ plot of $\mathrm{Ba}^{2+}$-resistant component. Voltage step size, $5 \mathrm{mV}$; pulse width, $100 \mathrm{msec}$; pulse frequency, $2 \mathrm{~Hz}$.

of PMNs (Cameron et al., 1984; C. Su and J. Feldman, unpublished observations).

We conclude that a $\mathrm{Ba}^{2+}$-sensitive $\mathrm{K}^{+}$component along with a $\mathrm{Ba}^{2+}$-resistant component underlies the inward current induced by $1 \mathrm{~S}, 3 \mathrm{R}-\mathrm{ACPD}$. One consequence of the inhibition of a tonic $\mathrm{K}^{+}$ conductance is an increase in cell excitability. Because this conductance contributes to the resting membrane potential, its inhibition by $1 \mathrm{~S}, 3 \mathrm{R}-\mathrm{ACPD}$ results in membrane depolarization, which brings the PMN closer to firing threshold. In addition, the accompanying increase in membrane resistance increases the gain between synaptic current and membrane depolarization. Thus, 1S,3R-ACPD facilitates the production of action potentials in response to depolarizing inputs; for PMNs, this means more action potentials for a given inspiratory-modulated synaptic drive.

\section{Possible mechanism and role of multiple actions of mGluRs in modulating synaptic transmission}

Activation of mGluRs by 1S,3R-ACPD exerts multiple effects on PMNs. A presynaptic action reduces transmitter release, which provides a negative (autoregulatory) feedback, whereas a postsynaptic action enhances the efficiency of synaptic transmission.

How are these different actions mediated? The mGluR family consists of at least eight distinct receptor subtypes: mGluR1mGluR8 (Houamed et al., 1991; Masu et al., 1991; Abe et al., 1992; Tanabe et al., 1992; Nakajima et al., 1993; Tanabe et al., 1993; Okamoto et al., 1994; Duvoisin et al., 1995). Multiple mGluR mRNAs are present in single neurons (Saugstad et al., 1994). Because 1S,3R-ACPD is a broad spectrum exogenous agonist interacting with each subtype, its diverse actions may result from activation of several receptor subtypes at different loci. We conclude that 1S,3R-ACPD exerts its facilitatory action on PMNs by inhibiting a postsynaptic resting $\mathrm{K}^{+}$conductance. If the same mechanism underlies its presynaptic action, synaptic transmission should be enhanced rather than suppressed, as we observed. Apparently, 1S,3R-ACPD-induced pre- and postsynaptic actions involve different mechanisms, suggesting the involvement of different receptor subtypes. The observation that the $\mathrm{K}^{+}$channel blocker $\mathrm{Ba}^{2+}$ did not alter 1S,3R-ACPD-induced depression of the synaptic transmission (Baskys et al., 1993) further supports this notion.

L-AP4, an mGluR4 agonist (Tanabe et al., 1993), depresses inspiratory-modulated synaptic drive to PMNs via a presynaptic action (Liu et al., 1990). We now find that 1S,3R-ACPD inhibits 
inspiratory-modulated postsynaptic currents in a manner similar to L-AP4. There is evidence showing that 1S,3R-1S,3R-ACPD does interact with mGluR4 (Thoreson and Miller, 1994; Flor et al., 1995); however, a form of 1S,3R-ACPD-induced presynaptic depression involves a component that is not mediated by the L-AP4 receptor (Cahusac, 1994; Jane et al., 1994; Lovinger and McCool, 1995). Thus, whether 1S,3R-ACPD and L-AP4 act on the same or distinct receptors to suppress synaptic transmission to PMNs remains unclear and requires further analysis.

Our data were obtained from neonates on postnatal days $0-4$. Although no significant developmental changes of response to 1S,3R-ACPD were found during this time period in our study, the potential for developmental differences might occur later. Indeed, there are changes in pharmacological profiles of mGluRs during development in other regions of brain (Baskys and Malenka, 1991; Becker et al., 1994; Manahan-Vaughan and Reymann, 1995; Mick et al., 1995; Reid et al., 1995; Vazquez et al., 1995). Therefore, caution must be taken when contemplating the relevance of data from neonates to those of adults. Regardless of the relevance of our observations to more mature animals, our data provide information of the involvement and mechanism of mGluRs in modulation of synaptic transmission to PMNs in rats during the early neonatal period.

In summary, activation of mGluRs by 1S,3R-ACPD affects inspiratory-modulated activity of PMNs. The actions consist of decrease of synaptic transmission and increase of excitability at pre- and postsynaptic sites, respectively. The balance of these contrary actions, along with other modulatory systems (e.g., 5-HT and adenosine) (Lindsay and Feldman, 1993; Dong and Feldman, 1995), presumably acts to ensure that the synaptic transmission of inspiratory drive to spinal respiratory motoneurons is well adjusted and produces the appropriate motor output under widely varying conditions of ventilatory drive.

\section{REFERENCES}

Abe T, Sugihara H, Nawa H, Shigemoto R, Mizuno N, Nakanishi S (1992) Molecular characterization of a novel metabotropic glutamate receptor mGluR5 coupled to inositol phosphate $/ \mathrm{Ca}^{2+}$ signal transduction. J Biol Chem 267:13361-13368.

Barkat M (1991) Signal detection and estimation. Boston: Artech House. Baskys A, Malenka RC (1991) Agonists at metabotropic glutamate receptors presynaptically inhibit EPSCs in neonatal rat hippocampus. J Physiol (Lond) 444:687-701.

Baskys A, Wang S, Wojtowicz JM (1993) Metabotropic agonist-induced changes in elementary synaptic events in the dentate gyrus neurons of the hippocampus. Funct Neurol [Suppl] 8:9.

Bayliss DA, Viana F, Berger AJ (1992) Mechanisms underlying excitatory effects of thyrotropin-releasing hormone on rat hypoglossal motoneurons in vitro. J Neurophysiol 68:1733-1745.

Becker T, Gombos G, de Barry J (1994) Changes of pharmacological properties of (1S,3R)-ACPD-sensitive glutamate binding sites in developing mouse cerebellum [published erratum appears in Neurochem Int (1995) 26:101]. Neurochem Int 25:253-262.

Cahusac PM (1994) Cortical layer-specific effects of the metabotropic glutamate receptor agonist $1 \mathrm{~S}, 3 \mathrm{R}-\mathrm{ACPD}$ in rat primary somatosensory cortex in vivo. Eur J Neurosci 6:1505-1511.

Cameron WE, Averill DB, Berger AJ (1984) Evidence for differential inputs to phrenic motoneurons based on dendritic morphology. In: Neurogenesis of central respiratory rhythm (Bianchi AL, DenavitSaubie M, eds), pp 230-233. Lancaster, UK: MTP.

Cartmell J, Kemp JA, Alexander SP, Hill SJ, Kendall DA (1992) Inhibition of forskolin-stimulated cyclic AMP formation by 1-aminocyclopentanetrans-1,3-dicarboxylate in guinea-pig cerebral cortical slices. J Neurochem 58:1964-1966.

Charpak S, Gahwiler BH, Do KQ, Knopfel T (1990) Potassium conductances in hippocampal neurons blocked by excitatory amino-acid transmitters. Nature 347:765-767.
Chio S, Lovinger DM (1996) Metabotropic glutamate receptor modulation of voltage-gated $\mathrm{Ca}^{2+}$ channels involves multiple receptor subtypes in cortical neurons. J Neurosci 16:36-45.

Desai MA, Conn PJ (1991) Excitatory effects of ACPD receptor activation in the hippocampus are mediated by direct effects on pyramidal cells and blockade of synaptic inhibition. J Neurophysiol 66:40-52.

Dong X-W, Feldman JL (1995) Modulation of inspiratory drive to phrenic motoneurons by presynaptic adenosine $A_{1}$ receptors. J Neurosci 15:3458-3467.

Dong X-W, Morin D, Feldman JL (1994) Metabotropic glutamate receptors attenuate inspiratory-modulated synaptic current in phrenic motoneurons. Soc Neurosci Abstr 20:1714.

Duvoisin RM, Zhang C, Ramonell K (1995) A novel metabotropic glutamate receptor expressed in the retina and olfactory bulb. J Neurosci 15:3075-3083.

Eaton SA, Jane DE, Jones PL, Porter RH, Pook PC, Sunter DC, Udvarhelyi PM, Roberts PJ, Salt TE, Watkins JC (1993) Competitive antagonism at metabotropic glutamate receptors by (S)-4-carboxyphenylglycine and (RS)alpha-methyl-4-carboxyphenylglycine. Eur J Pharmacol 244:195-197.

Fatt P, Katz B (1952) Spontaneous subthreshold activity at motor nerve endings. J Physiol (Lond) 117:109-128.

Feldman JL, Smith JC (1994) Neural control of respiratory pattern in mammals: an overview. In: Lung biology in health and disease: regulation of breathing (Dempsey J, Pack A, eds), pp 39-69. New York: Dekker.

Fisher ND, Nistri A (1993) Substance P and TRH share a common effector pathway in rat spinal motoneurones: an in vitro electrophysiological investigation. Neurosci Lett 153:115-119.

Flor PJ, Lukic S, Ruegg D, Leonhardt T, Knopfel T, Kuhn R (1995) Molecular cloning, functional expression and pharmacological characterization of the human metabotropic glutamate receptor type 4. Neuropharmacology 34:149-155.

Forsythe ID, Clements JD (1990) Presynaptic glutamate receptors depress excitatory monosynaptic transmission between mouse hippocampal neurones. J Physiol (Lond) 429:1-16.

Gereau RW, Conn PJ (1995) Multiple presynaptic metabotropic glutamate receptors modulate excitatory and inhibitory synaptic transmission in hippocampal area CA1. J Neurosci 15:6879-6889.

Glaum SR, Miller RJ (1992) Metabotropic glutamate receptors mediate excitatory transmission in the nucleus of the solitary tract. J Neurosci 12:2251-2258

Glaum SR, Miller RJ (1995) Presynaptic metabotropic glutamate receptors modulate omega-conotoxin-GVIA-insensitive calcium channels in the rat medulla. Neuropharmacology 34:953-964.

Glaum SR, Slater NT, Rossi DJ, Miller RJ (1992) Role of metabotropic glutamate (ACPD) receptors at the parallel fiber-Purkinje cell synapse. J Neurophysiol 68:1453-1462.

Guérineau NC, Gähwiler BH, Gerber U (1994) Reduction of resting K ${ }^{+}$ current by metabotropic glutamate and muscarinic receptors in rat CA3 cells: mediation by G-proteins. J Physiol (Lond) 474:27-33.

Guérineau NC, Bossu JL, Gähwiler BH, Gerber U (1995) Activation of a nonselective cationic conductance by metabotropic glutamatergic and muscarinic agonists in CA3 pyramidal neurons of the rat hippocampus. J Neurosci 15:4395-4407.

Hayashi Y, A Momiyama, Takahashi T, Ohishi H Ogawa-Meguro R, Shigemoto R, Mizuno N, Nakanishi S (1993) Role of a metabotropic glutamate receptor in synaptic modulation in the accessory olfactory bulb. Nature 366:687-690.

Hille B (1992) Ion channels of excitable membrane. Sunderland, MA: Sinauer.

Houamed KM, Kuijper JL, Gilbert TL, Haldeman BA, O'Hara PJ, Mulvihill ER, Almers W, Hagen FS (1991) Cloning, expression, and gene structure of a $G$ protein-coupled glutamate receptor from rat brain. Science 252:1318-1321.

Isaac JT, Nicoll RA, Malenka RC (1995) Evidence for silent synapses: implications for the expression of LTP. Neuron 15:427-434.

Jane DE, Jones PL, Pook PC, Salt TE, Sunter DC, Watkins JC (1993) Stereospecific antagonism by (+)-alpha-methyl-4-carboxyphenylglycine (MCPG) of (1S,3R)-ACPD-induced effects in neonatal rat motoneurones and rat thalamic neurones. Neuropharmacology 32:725-727.

Jane DE, Jones PL, Pook PC, Tse HW, Watkins JC (1994) Actions of two new antagonists showing selectivity for different sub-types of metabotropic glutamate receptor in the neonatal rat spinal cord. Br J Pharmacol 112:809-816.

Jones SW (1989) On the resting potential of isolated frog sympathetic neurons. Neuron 3:153-161. 
Koerner JF, Cotman CW (1981) Micromolar L-2-amino-4-phosphonobutyric acid selectively inhibits perforant path synapses from lateral entorhinal cortex. Brain Res 216:192-198.

Kullmann DM (1994) Amplitude fluctuations of dual-component EPSCs in hippocampal pyramidal cells: implications for long-term potentiation. Neuron 12:1111-1120.

Kullmann DM, Siegelbaum SA (1995) The site of expression of NMDA receptor-dependent LTP: new fuel for an old fire. Neuron 15:997-1002.

Lester RA, Jahr CE (1990) Quisqualate receptor-mediated depression of calcium currents in hippocampal neurons. Neuron 4:741-749.

Liao D, Hessler NA, Malinow R (1995) Activation of postsynaptically silent synapses during pairing-induced LTP in CA1 region of hippocampal slice. Nature 375:400-404

Lindsay AD, Feldman JL (1993) Modulation of respiratory activity of neonatal rat phrenic motoneurones by serotonin. J Physiol (Lond) 461:213-233.

Lindsay AD, Greer JJ, Feldman JL (1991) Phrenic motoneuron morphology in the neonatal rat. J Comp Neurol 308:169-179.

Liu G, Feldman JL (1992) Quantal synaptic transmission in phrenic motor nucleus. J Neurophysiol 68:1468-1471.

Liu G, Feldman JL, Smith JC (1990) Excitatory amino acid-mediated transmission of inspiratory drive to phrenic motoneurons. J Neurophysiol 64:423-436.

Llano I, Marty A (1995) Presynaptic metabotropic glutamatergic regulation of inhibitory synapses in rat cerebellar slices. J Physiol (Lond) 486:163-176.

Lovinger DM, McCool BA (1995) Metabotropic glutamate receptormediated presynaptic depression at corticostriatal synapses involves mGLuR2 or 3. J Neurophysiol 73:1076-1083.

Maki R, Robinson MB, Dichter MA (1994) The glutamate uptake inhibitor L-trans-pyrrolidine-2,4-dicarboxylate depresses excitatory synaptic transmission via a presynaptic mechanism in cultured hippocampal neurons. J Neurosci 14:6754-6762.

Manahan-Vaughan D, Reymann KG (1995) Regional and developmental profile of modulation of hippocampal synaptic transmission and LTP by AP4-sensitive mGluRs in vivo. Neuropharmacology 34:991-1001.

Masu M, Tanabe Y, Tsuchida K, Shigemoto R, Nakanishi S (1991) Sequence and expression of a metabotropic glutamate receptor. Nature 349:760-765.

McBain CJ, DiChiara TJ, Kauer JA (1994) Activation of metabotropic glutamate receptors differentially affects two classes of hippocampal interneurons and potentiates excitatory synaptic transmission. J Neurosci 14:4433-4445.

McCrimmon DR, Smith JC, Feldman JL (1989) Involvement of excitatory amino acids in neurotransmission of inspiratory drive to spinal respiratory motoneurons. J Neurosci 9:1910-1921.

Mick G, Yoshimura R, Ohno K, Kiyama H, Tohyama M (1995) The messenger RNAs encoding metabotropic glutamate receptor subtypes are expressed in different neuronal subpopulations of the rat suprachiasmatic nucleus. Neuroscience 66:161-173.

Morin D, Dong X-W, Feldman JL (1994) Metabotropic glutamate receptor-mediated increase of phrenic motoneuron (PMN) excitability in vitro. Soc Neurosci Abstr 20:1511.

Nakajima Y, Iwakabe H, Akazawa C, Nawa H, Shigemoto R, Mizuno N, Nakanishi S (1993) Molecular characterization of a novel retinal metabotropic glutamate receptor mGluR6 with a high agonist selectivity for L-2-amino-4-phosphonobutyrate. J Biol Chem 268:11868-11873.

Nicoll RA, Malenka RC, Kauer JA (1990) Functional comparison of neurotransmitter receptor subtypes in mammalian central nervous system. Physiol Rev 70:513-565.

Okamoto N, Hori S, Akazawa C, Hayashi Y, Shigemoto R, Mizuno N, Nakanishi S (1994) Molecular characterization of a new metabotropic glutamate receptor mGluR7 coupled to inhibitory cyclic AMP signal transduction. J Biol Chem 269:1231-1236.

Press WH, Flannery BP, Teukolsky SA, Vetterling WT (1989) Numerical recipes: the art of scientific computing. Cambridge: Cambridge UP.

Redman S (1990) Quantal analysis of synaptic potentials in neurons of the central nervous system. Physiol Rev 70:165-198.

Reid SN, Romano C, Hughes T, Daw NW (1995) Immunohistochemical study of two phosphoinositide-linked metabotropic glutamate receptors (mGluR1 alpha and mGluR5) in the cat visual cortex before, during, and after the peak of the critical period for eye-specific connections. J Comp Neurol 355:470-477.

Saugstad JA, Kinzie JM, Mulvihill ER, Segerson TP, Westbrook GL (1994) Cloning and expression of a new member of the L-2-amino-4phosphonobutyric acid-sensitive class of metabotropic glutamate receptors. Mol Pharmacol 45:367-372.

Sayer RJ, Schwindt PC, Crill WE (1992) Metabotropic glutamate receptor-mediated suppression of L-type calcium current in acutely isolated neocortical neurons. J Neurophysiol 68:833-842.

Scanziani M, Capogna M, Gahwiler BH, Thompson SM (1992) Presynaptic inhibition of miniature excitatory synaptic currents by baclofen and adenosine in the hippocampus. Neuron 9:919-927.

Schoepp D, Bockaert J, Sladeczek F (1990) Pharmacological and functional characteristics of metabotropic excitatory amino acid receptors. Trends Pharmacol Sci 11:508-515.

Schoepp DD, Johnson BG, Monn JA (1992) Inhibition of cyclic AMP formation by a selective metabotropic glutamate receptor agonist. J Neurochem 58:1184-1186.

Scholz KP, Miller RJ (1992) Inhibition of quantal transmitter release in the absence of calcium influx by a $\mathrm{G}$ protein-linked adenosine receptor at hippocampal synapses. Neuron 8:1139-1150.

Sladeczek F, Pin JP, Recasens M, Bockaert J, Weiss S (1985) Glutamate stimulates inositol phosphate formation in striatal neurones. Nature 317:717-719.

Smith JC, Feldman JL (1987) In vitro brainstem-spinal cord preparations for study of motor systems for mammalian respiration and locomotion. J Neurosci Methods 21:321-333.

Smith JC, Liu G, Feldman JL (1988) Intracellular recording from phrenic motoneurons receiving respiratory drive in vitro. Neurosci Lett 88:27-32.

Stefani A, Pisani A, Mercuri NB, Bernardi G, Calabresi P (1994) Activation of metabotropic glutamate receptors inhibits calcium currents and GABA-mediated synaptic potentials in striatal neurons. J Neurosci 14:6734-6743.

Sugiyama H, Ito I, Hirono C (1987) A new type of glutamate receptor linked to inositol phospholipid metabolism. Nature 325:531-533.

Swartz KJ, Merritt A, Bean BP, Lovinger DM (1993) Protein kinase C modulates glutamate receptor inhibition of $\mathrm{Ca}^{2+}$ channels and synaptic transmission. Nature 361:165-168.

Tanabe Y, Masu M, Ishii T, Shigemoto R, Nakanishi S (1992) A family of metabotropic glutamate receptors. Neuron 8:169-179.

Tanabe Y, Nomura A, Masu M, Shigemoto R, Mizuno N, Nakanishi S (1993) Signal transduction, pharmacological properties, and expression patterns of two rat metabotropic glutamate receptors, mGluR3 and mGluR4. J Neurosci 13:1372-1378.

Thoreson WB, Miller RF (1994) Actions of (1S,3R)-1aminocyclopentane-1,3-dicarboxylic acid (1S,3R-ACPD) in retinal ON bipolar cells indicate that it is an agonist at L-AP4 receptors. J Gen Physiol 103:1019-1034.

Trombley PQ, Westbrook GL (1992) L-AP4 inhibits calcium currents and synaptic transmission via a G-protein-coupled glutamate receptor. J Neurosci 12:2043-2050.

Tyler EC, Lovinger DM (1995) Metabotropic glutamate receptor modulation of synaptic transmission in corticostriatal co-cultures: role of calcium influx. Neuropharmacology 34:939-952.

Van der Kloot W (1991) The regulation of quantal size. Prog Neurobiol 36:93-130.

Vazquez E, Herrero I, Miras-Portugal MT, Sanchez-Prieto J (1995) Developmental change from inhibition to facilitation in the presynaptic control of glutamate exocytosis by metabotropic glutamate receptors. Neuroscience 68:117-124.

Winder DG, Conn PJ (1992) Activation of metabotropic glutamate receptors in the hippocampus increases cyclic AMP accumulation. J Neurochem 59:375-378.

Yamamoto C, Sawada S, Takada S (1983) Suppressing action of 2-amino-4-phosphonobutyric acid on mossy fiber-induced excitation in the guinea pig hippocampus. Exp Brain Res 51:128-134.

Yoshino M, Kamiya H (1995) Suppression of presynaptic calcium influx by metabotropic glutamate receptor agonists in neonatal rat hippocampus. Brain Res 695:179-185. 